\title{
Wiskott-Aldrich syndrome protein-mediated actin dynamics control type-I interferon production in plasmacytoid dendritic cells
}

\section{Citation}

Prete, F., M. Catucci, M. Labrada, S. Gobessi, M. C. Castiello, E. Bonomi, A. Aiuti, et al. 2013. "Wiskott-Aldrich syndrome protein-mediated actin dynamics control type-I interferon production in plasmacytoid dendritic cells." The Journal of Experimental Medicine 210 (2): 355-374. doi:10.1084/jem.20120363. http://dx.doi.org/10.1084/jem.20120363.

\section{Published Version}

doi:10.1084/jem.20120363

\section{Permanent link}

http://nrs.harvard.edu/urn-3:HUL.InstRepos:11855801

\section{Terms of Use}

This article was downloaded from Harvard University's DASH repository, and is made available under the terms and conditions applicable to Other Posted Material, as set forth at http:// nrs.harvard.edu/urn-3:HUL.InstRepos:dash.current.terms-of-use\#LAA

\section{Share Your Story}

The Harvard community has made this article openly available.

Please share how this access benefits you. Submit a story.

Accessibility 


\title{
Wiskott-Aldrich syndrome protein-mediated actin dynamics control type-I interferon production in plasmacytoid dendritic cells
}

\author{
Francesca Prete, ${ }^{1}$ Marco Catucci, ${ }^{2}$ Mayrel Labrada, ${ }^{1,3}$ Stefania Gobessi, ${ }^{4}$ \\ Maria Carmina Castiello, ${ }^{2,5}$ Elisa Bonomi, ${ }^{6}$ Alessandro Aiuti, ${ }^{2,7}$ \\ William Vermi, ${ }^{6,8}$ Caterina Cancrini, ${ }^{9}$ Ayse Metin, ${ }^{10}$ Sophie Hambleton, ${ }^{11}$ \\ Robbert Bredius, ${ }^{12}$ Luigi Daniele Notarangelo, ${ }^{13}$ Mirjam van der Burg, ${ }^{14}$ \\ Ulrich Kalinke, ${ }^{15}$ Anna Villa, ${ }^{2,16}$ and Federica Benvenuti ${ }^{1}$
}

\footnotetext{
IInternational Centre for Genetic Engineering and Biotechnology, Padriciano 99, 34149 Trieste, Italy

${ }^{2}$ San Raffaele Scientific Institute, Telethon Institute for Gene Therapy, 20132 Milan, Italy

${ }^{3}$ mmmunobiology Division, Center of Molecular Immunology, Atabey, Playa, Havana, Cuba

${ }^{4}$ International Centre for Genetic Engineering and Biotechnology (ICGEB) Molecular Hematology Group,

Campus "A. Buzzati-Traverso," 00016 Rome, Italy

${ }^{5}$ Vita-Salute San Raffaele University, 20132 Milan, Italy

${ }^{6}$ Department of Pathology, University of Brescia/Spedali Civilli di Brescia, 25123 Brescia, Italy

${ }^{7}$ Department of Public Health and Cell Biology, Tor Vergata University, 00133 Rome, Italy

${ }^{8}$ Department of Pathology and Immunology, Washington University School of Medicine, St. Louis, M0 63110

${ }^{9}$ Department of Pediatrics, Children's Hospital Bambino Gesù and Tor Vergata University, 00133 Rome, Italy

${ }^{10}$ Pediatric Immunology and Allergy Department, Ankara Children's Diseases Hematology Oncology Training Hospital Pediatric Hematology, Bone Marrow, Transplantation Unit, Ankara Children's Hematology Oncology Training Hospital, 06050 Ankara, Turkey

${ }^{11}$ Institute of Cellular Medicine, Newcastle University, Newcastle NE2 4HH, England, UK

${ }^{12}$ Department of Hematology and Immunology of Leiden University Medical Center, 2300 Leiden, Netherlands

${ }^{13}$ Division of Immunology, Children's Hospital, Harvard Medical School, Boston, MA 02115

${ }^{14}$ Department of Immunology, Erasmus MC, University Medical Center Rotterdam, 3015 GE Rotterdam, Netherlands

${ }^{15}$ Institute for Experimental Infection Research, TWINCORE, Centre for Experimental and Clinical Infection Research, a joint venture between the Helmholtz-Centre for Infection Research (HZI), Braunschweig, and the Hannover Medical School (MHH), 30625 Hannover, Germany

${ }^{16}$ Milan Unit, Istituto di Ricerca Genetica e Biomedica, Consiglio Nazionale delle Ricerche, 20138 Milan, Italy
}

\author{
CORRESPONDENCE \\ Federica Benvenuti: \\ benvenut@icgeb.org \\ Abbreviations used: BAFF, \\ $\mathrm{B}$ cell activating factor; $\mathrm{cDC}$, \\ conventional DC; EE, early \\ endosomes; HD, healthy donor; \\ HPF, high power field; IRF-7, \\ IFN regulatory factor 7; JIA, \\ juvenile idiopathic arthritis; \\ MxA, myxovirus resistance \\ protein A; pDC, plasmacytoid \\ DC; SLE, systemic lupus erythe- \\ matosus; WAS, Wiskott- \\ Aldrich syndrome; WASp, \\ WAS protein
}

Mutations in Wiskott-Aldrich syndrome (WAS) protein (WASp), a regulator of actin dynamics in hematopoietic cells, cause WAS, an X-linked primary immunodeficiency characterized by recurrent infections and a marked predisposition to develop autoimmune disorders. The mechanisms that link actin alterations to the autoimmune phenotype are still poorly understood. We show that chronic activation of plasmacytoid dendritic cells (pDCs) and elevated type-I interferon (IFN) levels play a role in WAS autoimmunity. WAS patients display increased expression of type-I IFN genes and their inducible targets, alteration in pDCs numbers, and hyperresponsiveness to TLR9. Importantly, ablating IFN-I signaling in WASp null mice rescued chronic activation of conventional DCs, splenomegaly, and colitis. Using WASp-deficient mice, we demonstrated that WASp null pDCs are intrinsically more responsive to multimeric agonist of TLR9 and constitutively secrete type-I IFN but become progressively tolerant to further stimulation. By acute silencing of WASp and actin inhibitors, we show that WASp-mediated actin polymerization controls intracellular trafficking and compartmentalization of TLR9 ligands in pDCs restraining exaggerated activation of the TLR9-IFN- $\alpha$ pathway. Together, these data highlight the role of actin dynamics in pDC innate functions and imply the pDCIFN- $\alpha$ axis as a player in the onset of autoimmune phenomena in WAS disease.

Wiskott-Aldrich syndrome (WAS) is an X-linked immunodeficiency characterized by thrombocytopenia, eczema, recurrent infections, and autoimmune phenomena. The disease is caused by mutations of the WAS gene that encodes the
- 2013 Prete et al. This article is distributed under the terms of an AttributionNoncommercial-Share Alike-No Mirror Sites license for the first six months after Noncommercial-Share Alike-No Mirror Sites license for the first six months after
the publication date (see http://www.rupress.org/terms). After six months it is available under a Creative Commons License (Attribution-Noncommercial-Share Alike 3.0 Unported license, as described at http://creativecommons.org/licenses/ by-nc-sa/3.0/). 
Table 1. PDC numbers and MxA expression in WAS spleen

\begin{tabular}{|c|c|c|c|c|}
\hline Case & MxA score & $M x A$ & pDCs & Clinical score/autoimmunity \\
\hline & & $\%$ & & \\
\hline WAS\# 1 & 4 & 18.52 & 6.21 & $5 /+$ \\
\hline WAS\#2 & 2 & 13.23 & 203.92 & $5 /-$ \\
\hline WAS\#3 & 3 & 7.99 & 154.98 & $5 /-$ \\
\hline WAS\#4 & 1 & 2.89 & 228.76 & $5 /+$ \\
\hline WAS\#5 & 4 & 19.02 & 50.40 & $3 /-$ \\
\hline WAS\# 6 & 2 & 1.03 & 93.71 & $3 /-$ \\
\hline WAS\#7 & 4 & 13.95 & 323.48 & $5 /+$ \\
\hline WAS\#8 & 4 & 13.61 & 8.68 & $5 /+$ \\
\hline Mean $( \pm S D)$ & 3 & $11.28( \pm 6.7)$ & $133.8( \pm 113.9)$ & \\
\hline CTR\# 1 & 3 & 14.44 & 131.15 & \\
\hline CTR\#2 & 1 & 0.47 & 578.25 & \\
\hline CTR\#3 & 2 & 1.6 & 202.63 & \\
\hline CTR\#4 & 2 & 0.15 & 223.00 & \\
\hline CTR\#5 & 2 & 4.21 & NV & \\
\hline CTR\# 6 & 4 & 25.29 & 202.63 & \\
\hline CTR\#7 & 2 & 10.24 & 156.26 & \\
\hline CTR\#8 & 2 & 0.61 & 62.95 & \\
\hline CTR\#9 & ne & ne & 83.21 & \\
\hline CTR\# 10 & 3 & 20.48 & 43.80 & \\
\hline Mean $( \pm S D)$ & 2.3 & $7.12( \pm 9.5)$ & $187.10( \pm 160.30)$ & \\
\hline
\end{tabular}

ne $=$ not evaluable. MxA is expressed as the percentage of reactivity of the spleen area. pDCs are expressed as BDCA-2 $2^{+}$cells/mm²spleen area. Absolute $\mathrm{pDC}$ count and MxA expression were quantified on spleen sections of WAS patients. The MxA score was evaluated by counting the percentage of MxA+ cells and expressed as a four-tier scale. MxA percentage of reactivity of the spleen area and BDCA-2+ cells $/ \mathrm{mm}^{2}$ spleen area were evaluated automatically on digital slides as described in Materials and methods. Disease score is given according to the classification reported previously (Imai et al., 2004)

WAS protein (WASp) involved in controlling actin dynamics. Members of the WASp family regulate a variety of actindependent processes that range from cell migration to phagocytosis, endocytosis, and membrane trafficking (Thrasher and Burns, 2010). Efforts to understand the cellular basis of the disease have identified diverse and cell-specific actin-related defects in cells of the adaptive and innate immune system. In $\mathrm{T}$ cells, TCR engagement induces cytoskeletal rearrangement, driving assembly of signaling platforms at the synaptic region. WASp plays a crucial role in this process by controlling ex novo actin polymerization required to stabilize synapse formation and signaling (Dupré et al., 2002; Sasahara et al., 2002; Badour et al., 2003; Snapper et al., 2005; Sims et al., 2007). WASp is also required on the APC side of the immune synapse for proper transmission of activating signals (Pulecio et al., 2008; Bouma et al., 2011). Defective signaling through antigen receptors affects the function of invariant natural killer T cells (Astrakhan et al., 2009; Locci et al., 2009) and B cells (Meyer-Bahlburg et al., 2008; Westerberg et al., 2008; BeckerHerman et al., 2011). Furthermore, altered actin polymerization and integrin signaling in WASp-deficient immune cells cause defective homing and directional migration of $\mathrm{T}, \mathrm{B}$, and DCs (de Noronha et al., 2005; Westerberg et al., 2005; Gallego et al., 2006). Moreover, WASp-mediated actin polymerization controls phagocytic cup formation in monocytes, macrophages, and DCs (Leverrier et al., 2001; Tsuboi, 2007) and it is involved in polarization and secretion of cytokine/ cytotoxic granules in T cells/NK cells (Orange et al., 2002; Gismondi et al., 2004; Morales-Tirado et al., 2004; Trifari et al., 2006). Together, the cellular defects identified in WASpdeficient immune cells provide clues to understand the immunodeficiency of WAS patients. However, the mechanisms by which perturbation of actin dynamics promote autoimmune phenomena are less clear. Impairment of $\mathrm{T}$ and $\mathrm{B}$ cell tolerance have been reported in WAS patients and in Wasdeficient mice, but the exact cellular mechanisms that link loss of WASp function to autoimmunity have not been fully elucidated yet (Humblet-Baron et al., 2007; Maillard et al., 2007; Marangoni et al., 2007; Becker-Herman et al., 2011; Recher et al., 2012).

Plasmacytoid DCs (pDCs) are the major class of type-I IFN-producing cells that react rapidly upon pathogen encounter to secrete large amount of this cytokine. Recognition of foreign nucleic acid by TLR7 and TLR9 occurs in endosomes and leads to production of type-I IFN and proinflammatory cytokines. Several studies have unveiled that activation of IFN regulatory factor 7 (IRF-7) and IFN- $\alpha$ production in pDCs relies upon strict spatiotemporal compartmentalization of TLR 9 and its ligands within the endocytic pathway (Honda et al., 2005; Guiducci et al., 2006; Sasai et al., 2010).

Besides their beneficial antiviral properties, type-I IFNs produced by $\mathrm{pDCs}$ contribute to breakage of tolerance in several 
human autoimmune diseases, including systemic lupus erythematosus (SLE), Sjogren syndrome, and psoriasis (Blanco et al., 2001; Båve et al., 2005; Nestle et al., 2005; Gottenberg et al., 2006; Becker-Herman et al., 2011). In these diseases, uncontrolled pDC activation depends on triggering of TLR7/9 by self-nucleic acid-containing immune complexes (Barrat et al., 2005), binding of self-DNA to antimicrobial peptides (Lande et al., 2007), and clustering of self-DNA within neutrophil extracellular traps (Garcia-Romo et al., 2011).

The most common autoimmune features that develop in a high proportion of WAS patients include hemolytic anemia, vasculitis, renal disease, and arthritis (Humblet-Baron et al., 2007; Bosticardo et al., 2009). These symptoms partially overlap with those commonly observed in type-I IFNdriven diseases. Based on this, we hypothesized an involvement of the pDC-IFN- $\alpha$ axis in promoting autoimmunity in WAS. We provide evidences in patients and the demonstration in a mouse model that WASp deficiency in pDCs controls activation of IFN-I genes contributing to autoimmune phenomena in WAS.

\section{RESULTS}

\section{Frequency of pDCs and expression of type-I IFN-inducible genes in WAS patients}

Dysregulated production of type-I IFN by pDCs represents a crucial step in the pathogenesis of autoimmune diseases such as SLE, Sjogren syndrome, and psoriasis. Some typical features of these diseases, such as skin lesions, arthritis, renal diseases, and cutaneous vasculitis, are also present in a proportion of WAS patients. Moreover, autoantibodies that are known to convert self-nucleic acid into potent triggers of pDCs are abundant in a murine model of WAS deficiency and are also detected in a proportion of WAS patients (DupuisGirod et al., 2003; Meyer-Bahlburg et al., 2008; Trifari et al., 2010; Becker-Herman et al., 2011; Bosticardo et al., 2011). To investigate a possible contribution of altered pDC homeostasis to the pathophysiology of WAS, we first analyzed spleen sections and peripheral blood of WAS patients. We previously reported a general depletion of the splenic white pulp in WAS spleen. However, this analysis was limited to lymphoid cell populations with no data on the occurrence and distribution of pDCs (Vermi et al., 1999). The availability of an anti-BDCA-2 capable to specifically identify human pDC on fixed tissues (Vermi et al., 2011) allowed us to analyze this cellular population of archival samples. Histological analysis of WAS spleen sections detected variable numbers of BDCA $-2^{+}$cells showing a typical pDCs morphology and a regular distribution in the $\mathrm{T}$ cell area (Table 1 and Fig. 1, A-D). The mean number of pDCs in WAS spleen was comparable to control cases (133.7 vs. 183.6; $\mathrm{P}=0.35$ ) with two cases in which pDCs were almost absent (Fig. $1 \mathrm{G}$ and Table 1). As a surrogate marker of type-I IFN production, we directly assessed the protein level of myxovirus resistance protein A (MxA) on human spleen by immunohistochemistry. Interestingly, we detected an elevated expression of MxA (score $\geq 3$ ) in five out of eight WAS patients

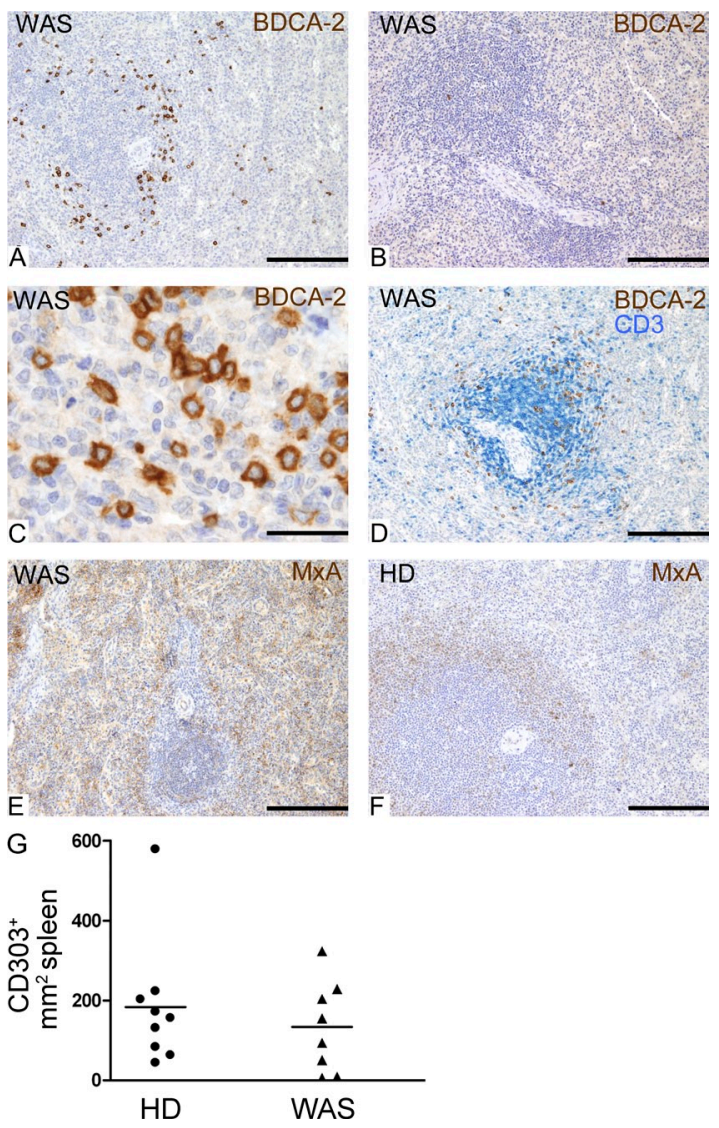

Figure 1. Characterization of pDCs cells in spleen and peripheral blood of WAS patients. Spleen sections are obtained from WAS patients $(A-E)$ and $H D s(F)$ and stained for BDCA-2+ (A-D, brown), CD3 (D, blue), and $\mathrm{M} \times \mathrm{A}$ ( $\mathrm{E}$ and F). Similarly to control cases, the spleen content of BDCA-2 $2^{+}$cells in WAS patients is extremely variable (WAS\#2 in A, WAS\# 1 in $B ; G)$. BDCA-2+ cells show a typical PDC morphology (WAS\#2 in C) and are regularly distributed mainly in T cell area (WAS\#2 in D). E and F illustrate two cases of MxA score 4 (WAS\#1) and score 2 (HD\#2). Bars:

( $A, B$, and D-F) $200 \mu \mathrm{m} ;$ (C) $33 \mu \mathrm{m}$. (G) The number of pDCs (CD303+ cells) in spleen sections was quantified automatically as described in Materials and methods. Horizontal bars indicate the mean value.

(Fig. 1, E and F). Significantly, in three of these cases, elevated MxA expression correlates to the occurrence of autoimmunity (Table 1). Several studies have shown that sera from SLE patients trigger $\mathrm{pDCs}$ activation and IFN- $\alpha$ release (Vallin et al., 1999; Lövgren et al., 2004; Barrat et al., 2005). To test this hypothesis in WAS, we incubated pDCs isolated from healthy donors (HDs) with sera derived from WAS patients or HDs. As a control, we included sera from patients with SLE and juvenile idiopathic arthritis (JIA). We observed induction of low to moderate production of IFN- $\alpha$ by WAS sera that was statistically significant as compared with HD sera and similar to the induction by SLE and JIA sera (Fig. 2 A). A second hallmark of type-I IFN-driven disease is the up-regulation of IFN- $\alpha$ gene transcripts in peripheral blood (Baechler et al., 2003, 2007; van der Pouw Kraan et al., 2007; Emamian et al., 2009; van Baarsen et al., 2009; Pascual et al., 2010). We analyzed 

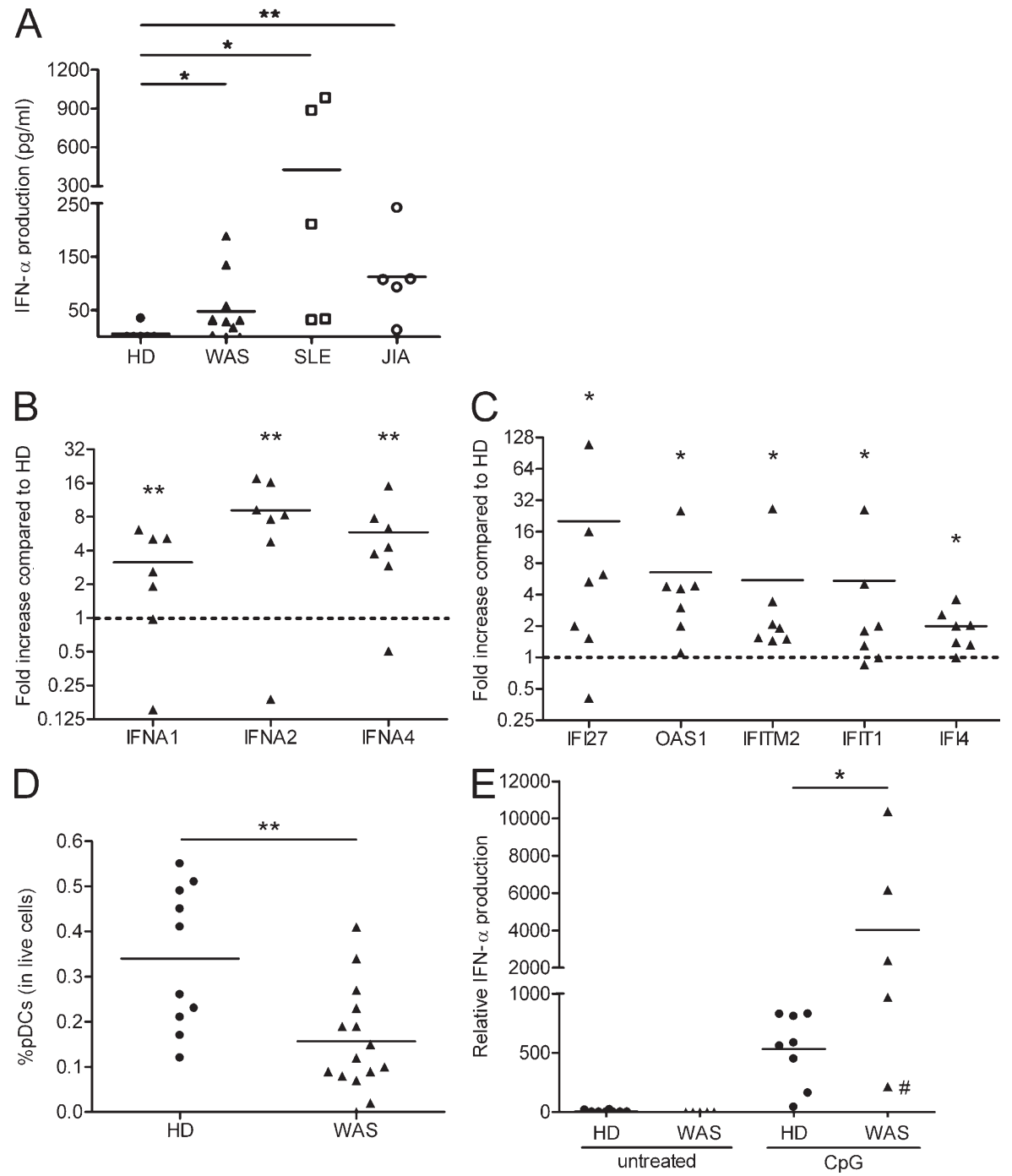

Figure 2. Characterization of pDCs in peripheral blood of WAS patients.

(A) IFN- $\alpha$ induction in pDCs by serum from WAS patients. pDCs isolated from HDs were incubated with 50\% serum from WAS, SLE, JIA patients, or HDs for $24 \mathrm{~h}$. IFN- $\alpha$ in supernatant was measured by ELISA. Values of IFN- $\alpha$ supernatants were subtracted from the values of IFN- $\alpha$ in corresponding sera assayed in parallel without cells. Horizontal bars indicate the mean value. Data were analyzed with MannWhitney test. ${ }^{*}, \mathrm{P}<0.05 ;{ }^{* *}, \mathrm{P}<0.01$.

( $B$ and $C$ ) mRNA was extracted from PBMCs of seven WAS patients and five HDs. Data show expression of three IFN- $\alpha$ transcripts (B) and five type-I IFN-inducible genes (C). Horizontal bars indicate the mean value. Horizontal dashed line indicates the normalized HD mean value. (D) The percentage of pDCs in PBMCs of 15 pediatric WAS patients and 10 agematched HDs was calculated by dividing the number of lineage-negative/BDCA-2+/CD4+ cells by the number of total live cells. Horizontal bars indicate mean values. (E) Relative IFN- $\alpha$ production by PBMCs from five WAS patients and eight HDs $24 \mathrm{~h}$ after stimulation with CpG ODN2216. Relative IFN- $\alpha$ production was calculated by dividing $\mathrm{CpG}$ ODN2216-induced IFN- $\alpha$ production by the percentage of $\mathrm{pDCs}$. Adult patient is indicated by \#. ELISA and real-time PCR data were analyzed with Mann-Whitney test. ${ }^{*}, P<0.05$; ${ }^{*}, \mathrm{P}<0.01$. the expression of type-I IFN genes and IFN- $\alpha$-inducible targets (chosen among those found overexpressed in SLE patients) in a cohort of seven WAS patients with a clinical score of 4-5. Notably, we observed increased expression of IFN- $\alpha$ genes in six of seven patients analyzed (Fig. 2 B). Moreover, the mean expression levels of five type-I IFNinduced genes were significantly higher in this cohort of patients compared with age-matched HDs (Fig. 2 C). Next, we examined the frequency and responsiveness of the $\mathrm{pDC}$ compartment in PBMCs. In keeping with previous observations in SLE (Blomberg et al., 2003; Migita et al., 2005; Kwok et al., 2008b), we found a reduction in the frequency of pDCs in the PBMC of 15 pediatric WAS patients with a severe clinical score (3-5, described by Zhu et al., 1997) as compared with HDs (Fig. 2 D). Next we evaluated the capacity of WAS pDCs to produce IFN- $\alpha$ in response to an agonist of TLR9. We stimulated total PBMCs using a pDC-specific TLR9 ligand, $\mathrm{CpG}$ ODN2216. Since pDC frequency was different among WAS patients and HDs, we calculated the relative IFN- $\alpha$ production dividing the absolute IFN- $\alpha$ production evaluated by ELISA by the percentage of pDCs in each sample (Fig. 2 E). We found that the relative IFN- $\alpha$ production by WAS patients was significantly higher compared with HDs (Fig. 2 E). Overall these data strongly suggest that the pDC-IFN- $\alpha$ axis can be altered in WAS patients, thus contributing to pathogenesis of autoimmune manifestations.

\section{Constitutive activation and spontaneous IFN- $\alpha$ release by WASp-deficient $\mathrm{pDCs}$}

To better understand the role of WASp in pDC, we moved to study a mouse model of WAS. Mice knocked out for WASp protein expression (WKO mice) present circulating autoantibodies and develop spontaneous colitis and proliferative glomerulonephritis with immune complex deposition (Snapper et al., 1998; Humblet-Baron et al., 2007; Nikolov et al., 2010; Shimizu et al., 2012). Mutant mice also show infiltrates of $\mathrm{B}, \mathrm{T}$, and DCs in salivary glands, a feature commonly observed in mice models of Lupus and Sjogren Syndrome, and a moderate proteinuria index indicative of renal damage (not depicted; Humphreys-Beher, 1996; Fleck et al., 1998). 

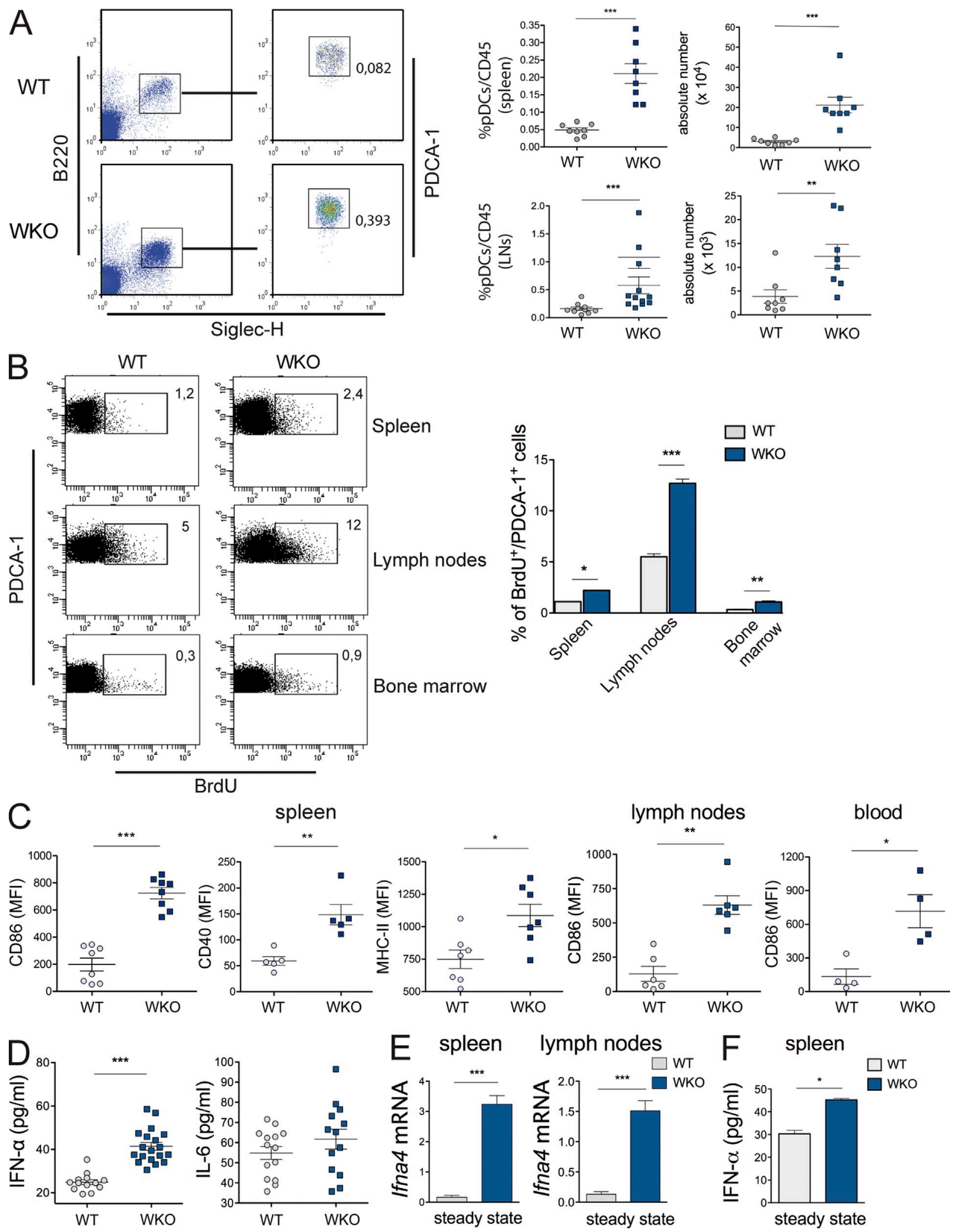

Figure 3. Analysis of the pDC compartment in WASp-deficient mice. (A) Frequency and absolute numbers of pDCs in adult WKO mice. FACS dot plots show pDCs gating strategies, and numbers in quadrants refer to percentage of PDCA-1+/Siglec- $\mathrm{H}^{+} / \mathrm{B} 22 \mathrm{O}^{+}$cells. Graphs show frequency and absolute number of pDCs in the spleen and LN of WT and WKO animals. $n=8-11$ mice per group from three independent experiments. (B) Proliferation of pDCs in vivo. WT and WKO adult mice were fed BrdU in the drinking water for $7 \mathrm{~d}$. Representative FACS plots showing the percentages of BrdU+ $p D C s$ in spleen, 
We first analyzed the pDC compartment in WKO mice. Conversely to patients, we found that the frequency and $\mathrm{ab}-$ solute numbers of PDCA-1 $1^{+} /$Siglec- $\mathrm{H}^{+} / \mathrm{B} 220^{+}$cells were higher both in spleen and LNs of WKO mice (Fig. 3 A). To understand the origin of increased cell numbers, we performed an in vivo BrdU labeling experiment by feeding WT and WKO mice for $7 \mathrm{~d}$ with BrdU in the drinking water. The number of labeled pDCs in the spleen, LNs, and BM was twice as much in WKO than in WT animals, indicating an enhanced turnover rate (Fig. $3 \mathrm{~B}$ ). WKO pDCs express significantly higher levels of MHC class-II and costimulatory molecules (CD40 and CD86) in spleen, LNs, and blood, further indicating a state of constitutive activation (Fig. $3 \mathrm{C}$ ). To examine whether chronically activated pDCs may be a source of elevated IFN- $\alpha$, we analyzed the sera of WT and WKO mice. As shown in Fig. $3 \mathrm{D}$, in the absence of any in vivo stimulation, significantly higher levels of IFN- $\alpha$ were detected in the serum of WKO than of WT mice; in contrast, levels of the inflammatory cytokine IL-6 were similar in both groups of mice. Circulating IFN- $\alpha$ at steady state is not simply a consequence of increased pDC numbers, as mRNA extracted from equal numbers of splenic and LN pDCs confirmed the presence of IFN- $\alpha$ transcripts only in WKO pDCs (Fig. 3 E). Moderate levels of IFN- $\alpha$ protein were also detected in the supernatant of WKO splenic pDCs incubated ex vivo in medium without stimuli (Fig. 3 F). Thus, pDCs in WASp-deficient animals are spontaneously activated and constitutively secrete detectable amounts of type-I IFN.

\section{WKO pDCs develop a selective exhaustion of the TLR9-IFN- $\alpha$ pathway}

To further examine functional abnormalities in WASp-deficient pDCs, we evaluated their response to exogenous TLR agonists. WT and WKO mice were challenged intravenously with CpG-A-DOTAP, which induces secretion of high levels of type-I IFN by pDCs in the spleen. In WT mice, the levels of IFN- $\alpha$ peaked at $6 \mathrm{~h}$ after injection, whereas we detected a significantly lower IFN- $\alpha$ production in WKO mice at all time points tested (Fig. 4 A). The levels of IL-6 and IL-12p40 were comparable in the two genotypes (Fig. 4 A). Similarly, intracellular staining of splenic pDCs showed increasing numbers of IFN- $\alpha$-producing pDCs at 2.5 and $6 \mathrm{~h}$ after injection in WT mice, whereas lower percentages of positive cells were detected in WKO mice at all time points (Fig. 4 B). We next evaluated the production of type-I IFN and inflammatory cytokines in cells stimulated ex vivo with agonists of TLR 9 and
TLR7. We used two agonists of TLR9: multimeric CpG-A, which induces robust IRF-7-mediated transcription of IFN- $\alpha$ genes and little proinflammatory cytokines, and $\mathrm{CpG}-\mathrm{B}$, which induces preferentially inflammatory cytokines. As an agonist of TLR7, we used Imiquimod (R837; Honda et al., 2005). As expected, multimeric CpG-A, R837, and, to a lower extent, CpG-B induced IFN- $\alpha$ gene transcription and protein secretion in WT pDCs (Fig. 4 C). In contrast, IFN- $\alpha$ production was strongly impaired in WKO pDCs in response to agonist of TLR7 and TLR9, both at the transcriptional and protein level. Release of inflammatory cytokines varied depending on the agonist used but was overall similar in WT and WKO pDCs (Fig. 4, C and D). In sum, these data show that pDCs in adult WKO mice are hyporesponsive in terms of IFN- $\alpha$ while maintaining intact the capacity to produce inflammatory cytokines upon TLR7/9 triggering. This is consistent with the fact that chronically activated pDCs become refractory to further TLR challenge (Pau et al., 2012).

\section{WKO $\mathrm{pDCs}$ are intrinsically more responsive to TLR9 triggering}

We next investigated the mechanism of altered pDC functions. First, we tested whether spontaneous pDC activation may depend on the presence of endogenous pDC activators in sera, as seen in WAS patients. We confirmed that serum from adult WKO contains autoantibodies (Humblet-Baron et al., 2007; Becker-Herman et al., 2011; Recher et al., 2012). As shown in Fig. 5 (A and B), we found anti-nuclear and anti-double-stranded (ds) DNA antibodies in adult WKO mice that are absent in younger animals (3 wk; Fig. 5, A and B). Stimulation of pDCs with sera from adult WKO mice (6-12 wk), but not with sera from adult WT mice, induced IFN- $\alpha$ gene transcription and release of little but detectable amounts of IFN- $\alpha$ in the cell culture supernatant. Sera from young WKO mice failed to induce IFN- $\alpha$ secretion. Moreover, the IFN- $\alpha$-inducing capacity of WKO sera was reduced upon pretreatment with DNase (Fig. 5 D). Thus, immune complexes of autoantibodies and self-nucleic acid may constitute an endogenous trigger of $\mathrm{pDC}$ activation in vivo in WAS mice. Activation by endogenous factors would explain, at least in part, chronic pDC activation and exhaustion of the IFN- $\alpha$ pathway, similarly to what has been described in SLE (Ito et al., 2006; Kwok et al., 2008a).

However, a second not mutually exclusive hypothesis is that cell intrinsic factors lower the threshold for pDC activation. Consistent with this, WKO B cells were recently shown to be intrinsically hyperresponsive to TLR9 triggering

LN, and BM. Results are from two experiments with four mice per group. (C) The expression of maturation markers (CD86, CD40, and MHC-II) was measured by FACS on pDCs in different organs. The mean fluorescence intensity (MFI) in individual mice is indicated. Data are representative of two experiments ( $n=4-8$ mice per group) of four performed. (D) The levels of IFN- $\alpha$ and IL-6 in the sera of untreated mice were evaluated by ELISA. $n=13-14$ WT mice and 13-19 WKO mice. (E) Data show the relative expression of Ifna 4 mRNA in pDCs isolated from the spleen and LN of WT and WKO mice. $\triangle C T s$ were obtained by normalizing target gene to the housekeeping $\beta$-actin. Values are shown as the $2^{\Delta C T} \times 10^{3} . n=4$ mice per group in at least four independent experiments. (F) WT and WKO splenic pDCs were plated at $3 \times 10^{5} /$ well and the spontaneous release of IFN- $\alpha$ was measured by ELISA $24 \mathrm{~h}$ later. Data are from three independent experiments, each with six mice per group. A-C, Mann-Whitney test; D-F, Student's $t$ test; error bars indicate SEM. ${ }^{*}, \mathrm{P}<0.05 ;{ }^{* *}, \mathrm{P}<0.01 ;{ }^{* * *}, \mathrm{P}<0.001$. 

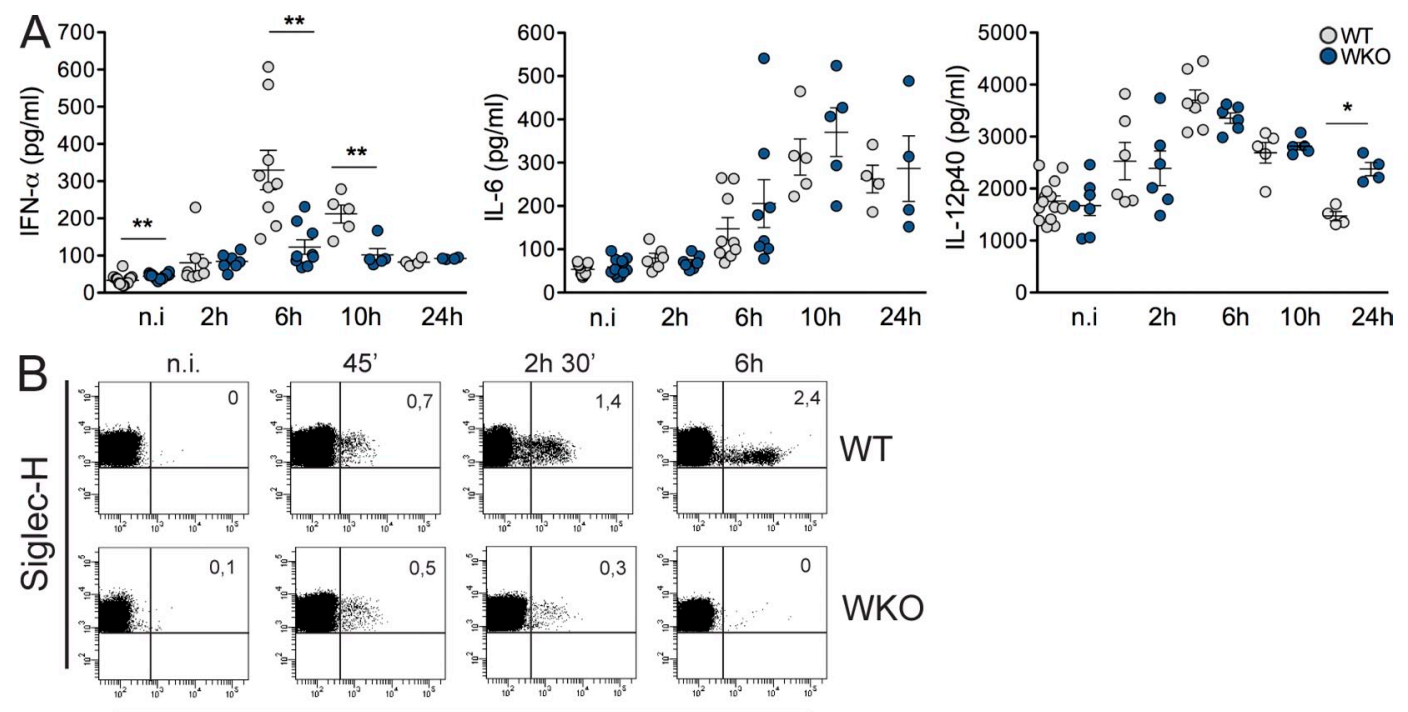

IFN- $\alpha$
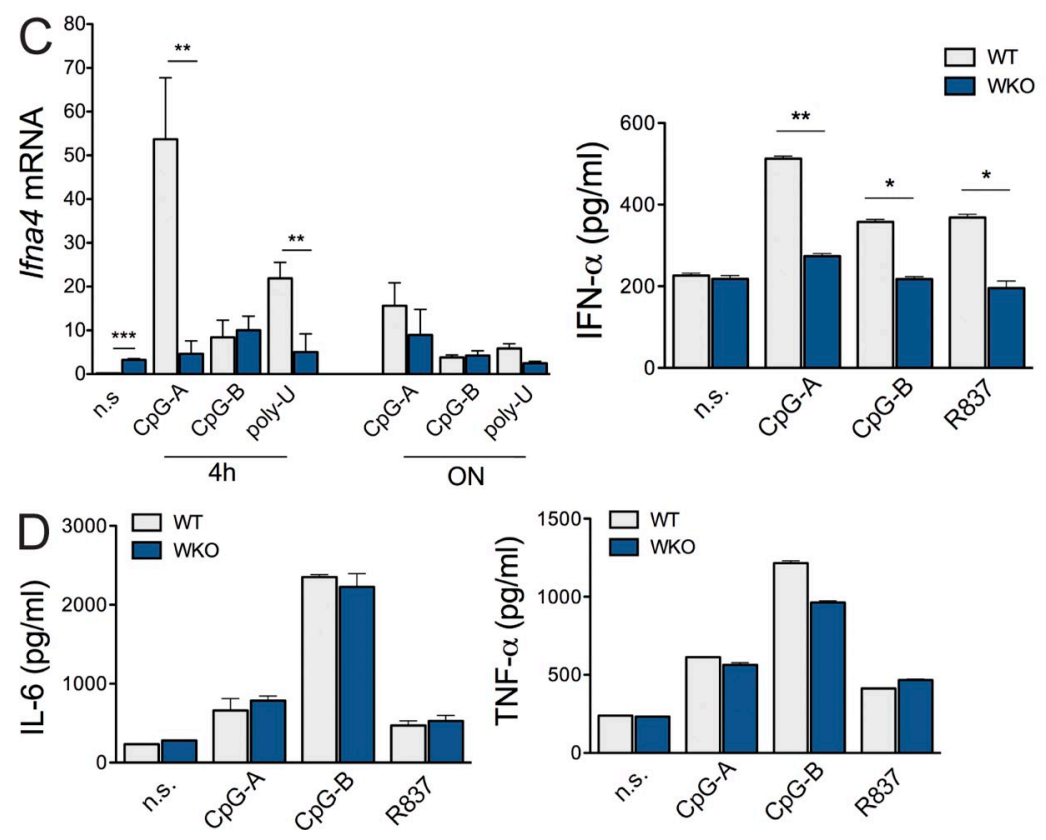

Figure 4. Progressive exhaustion of the TLR9/IFN- $\alpha$ in WKO mice. (A) WT and WKO adult ( $>6$ wk) mice were injected intravenously with $10 \mu g$ CpG-A in complex with the cationic lipid DOTAP. Serum levels of IFN- $\alpha, I L-6$, and IL-12p40 were measured by ELISA at 2, 6, 10, and $24 \mathrm{~h}$ after injection. $n=4-9$ mice per group in three independent experiments. (B) Dot plots showing IFN- $\alpha$ intracellular staining in the spleen of WT and WKO mice isolated at different time points after injection. Numbers represents the percentage of cells in the respective quadrant. Data are representative of one of three experiments performed each with three mice per group. (C) Gene transcription and protein release in splenic pDCs sorted from WT and WKO adult mice. Cells were stimulated ex vivo with $\mathrm{CpG}-\mathrm{A}, \mathrm{CpG}-\mathrm{B}$, and R837 $(15 \mu \mathrm{g} / \mathrm{ml})$. The relative expression of Ifna 4 transcripts was evaluated by qRT-PCR at 4 and $24 \mathrm{~h}$. The target mRNA was normalized to $\beta$-actin mRNA. Values are shown as the $2^{\Delta C T} \times 10^{3}$. The levels of IFN- $\alpha$ (C, right), IL-6, and IL-12p40 (D) were measured in cell culture supernatants after $16 \mathrm{~h}$. Results are representative of four (CpG-A and $\mathrm{CpG}-\mathrm{B}$ in $\mathrm{C}$ ) and three (R837 in $\mathrm{C}$ and $\mathrm{D}$ ) independent experiments. A, Mann-Whitney test; $C$ and $D$, Student's $t$ test; error bars indicate SEM. ${ }^{*}, P<0.05 ;{ }^{* *}, P<0.01 ;{ }^{* *}, P<0.001$.

(Becker-Herman et al., 2011; Recher et al., 2012). To address this possibility, we first examined the responsiveness of naive pDCs isolated from young ( $3 \mathrm{wk}$ old) mice with undetectable anti-nuclear antibodies. We found that CpG-A, but not $\mathrm{R} 837$, induced a significantly enhanced production of IFN $-\alpha$ by WKO young pDCs (Fig. 6 A). Hyperresponsiveness to
CpG-A was also reflected in slightly enhanced IL-6 production that, despite being only weakly induced by this agonist, was augmented in WKO cells. TNF production in the cell culture supernatant was comparable between WT and WKO; however, intracellular staining at early time points revealed a higher fraction of cells positive for both IFN-I and TNF in 
A
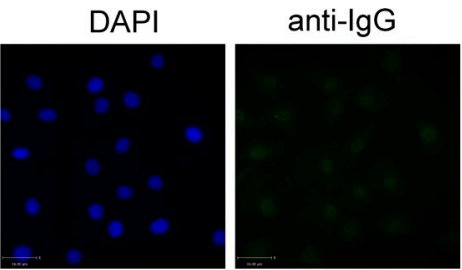

WKO
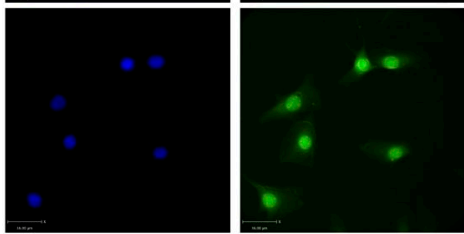

(3 weeks)
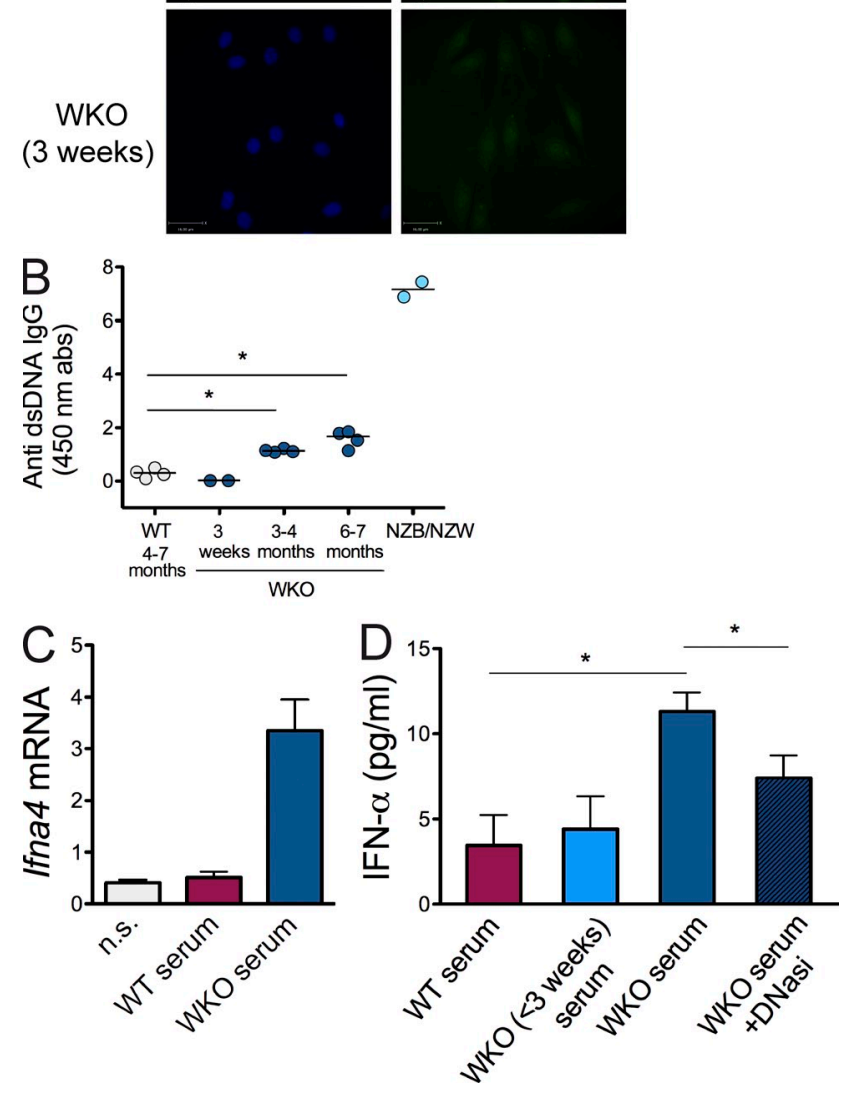

Figure 5. WKO serum induces IFN- $\alpha$ secretion by $\mathrm{pDCs}$. (A) The presence of $\lg G$ anti-dsDNA autoantibodies in sera was analyzed by immunostaining of NIH3T3 cells. Diluted sera from control (WT), WKO ( $>6 \mathrm{mo}$ ), and young WKO (3 wk) mice were incubated with NIH3T3 cells, and the anti-nuclear reactivity was detected using FITC-conjugated anti-IgG antibody (right). Nuclei were visualized by DAPI staining (left). Representative images from one out of four sera tested/group are shown. Bar, $36 \mu \mathrm{M}$. (B) Levels of IgG anti-dsDNA autoantibodies were evaluated by ELISA in sera (1:800 dilution) from 3-wk-old, 3-4-mo-old, and 6-7-mo-old WKO mice. As positive and negative controls, SLE-prone NZW/NZB F1 mice (6 mo old) and WT mice (4-7 mo old) were used, respectively. Each dot represents an individual animal. Horizontal bars indicate medians. (C) $3.5 \times 10^{5}$ WT BM-derived pDCs (BM-pDCs) were stimulated with sera from WT or WKO mice for $7 \mathrm{~h}$. Relative expression of Ifna 4 transcripts were evaluated by qRT-PCR. Data are representative of sera from $n=4$ mice per group in two independent experiments. (D) $3.5 \times 10^{5}$ WT BMpDCs were stimulated with sera from the indicated groups of animals (pooled sera of four animals per group) treated or not with DNase I.
WKO pDCs stimulated by CpG-A (Fig. 6 B). CpG-B and R837 induced equal levels of IFN- $\alpha$ and cytokines in the two groups. Notably, young WKO pDCs responded more vigorously than young WT pDCs to stimulation with sera derived from adult WKO animals (Fig. 6 C). Collectively, these data strongly suggest that naive WKO pDCs are hyperresponsive, especially in terms of IFN- $\alpha$ production, to multimeric TLR9 agonists (CpG-A and DNA immune complexes in sera). To fully establish that WASp controls activation of the TLR9-IFN- $\alpha$ pathway and to demonstrate that pDC dysregulation is cell autonomous, we treated pDCs with siRNA oligos that target WASp. WT pDCs treated with a Was-specific siRNA showed a $70 \%$ reduction in protein expression compared with cells treated with a control siRNA (Fig. 6 D). CpG-A stimulation of WASp-depleted cells induced significantly higher IFN $-\alpha$ and slightly increased IL-6, as compared with cells treated with the control siRNA, whereas inflammatory cytokines induced by CpG-B were comparable (Fig. 6 D). In a parallel experiment of gene depletion in conventional BM-derived DCs, we observed no differences in the levels of IL-6 and IL12p40 produced after stimulation with CpG-B (Fig. 6 E). Thus, in a setting that completely excludes environmental factors, full expression of WASp is required to control activation of the TLR 9 pathway intrinsically in pDCs. Interestingly, interfering with actin polymerization by means of two different actin inhibitors, cytochalasin-D and latrunculin-A, significantly enhanced IFN- $\alpha$ and slightly enhanced IL-6 release upon CpG-A triggering. The release of proinflammatory cytokines upon $\mathrm{CpG}-\mathrm{B}$ treatment was not affected (Fig. 6, F and G). Cytokine production by conventional DCs (cDCs) was also not modified by cytochalasin-D treatment (Fig. $6 \mathrm{H}$ ). Therefore, we conclude that in a cell-intrinsic fashion, WASp-mediated actin dynamics controls activation of TLR 9 signaling upon internalization of multimeric TLR9 ligands.

\section{Altered endocytic pathway and $\mathrm{CpG}-\mathrm{A}$ accumulation in WASp null pDCs}

We next examined the cell biological basis of increased IFN- $\alpha$ production in WASp null $\mathrm{pDCs}$. The unique ability of pDCs to produce large amounts of type-I IFN depends on spatiotemporal regulation of ligand/receptor trafficking within the endocytic pathway. It has been widely documented that retention of large DNA aggregates into early endosomes (EE) and trafficking to lysosome-related organelles are two steps that control robust activation of IFN- $\alpha$ genes (Honda et al., 2005; Guiducci et al., 2006; Sasai and Iwasaki, 2011). As recent reports showed that nucleating promoting factors like the Arp2/3 complex (a downstream WASp effector),

Secretion of IFN- $\alpha$ was measured by ELISA at $24 \mathrm{~h}$. Data are expressed as the values in experimental wells subtracted of the values in control wells (dilutions of sera without cells). B and D, Mann-Whitney test; error bars indicate SEM. ${ }^{*}, \mathrm{P}<0.05$. 

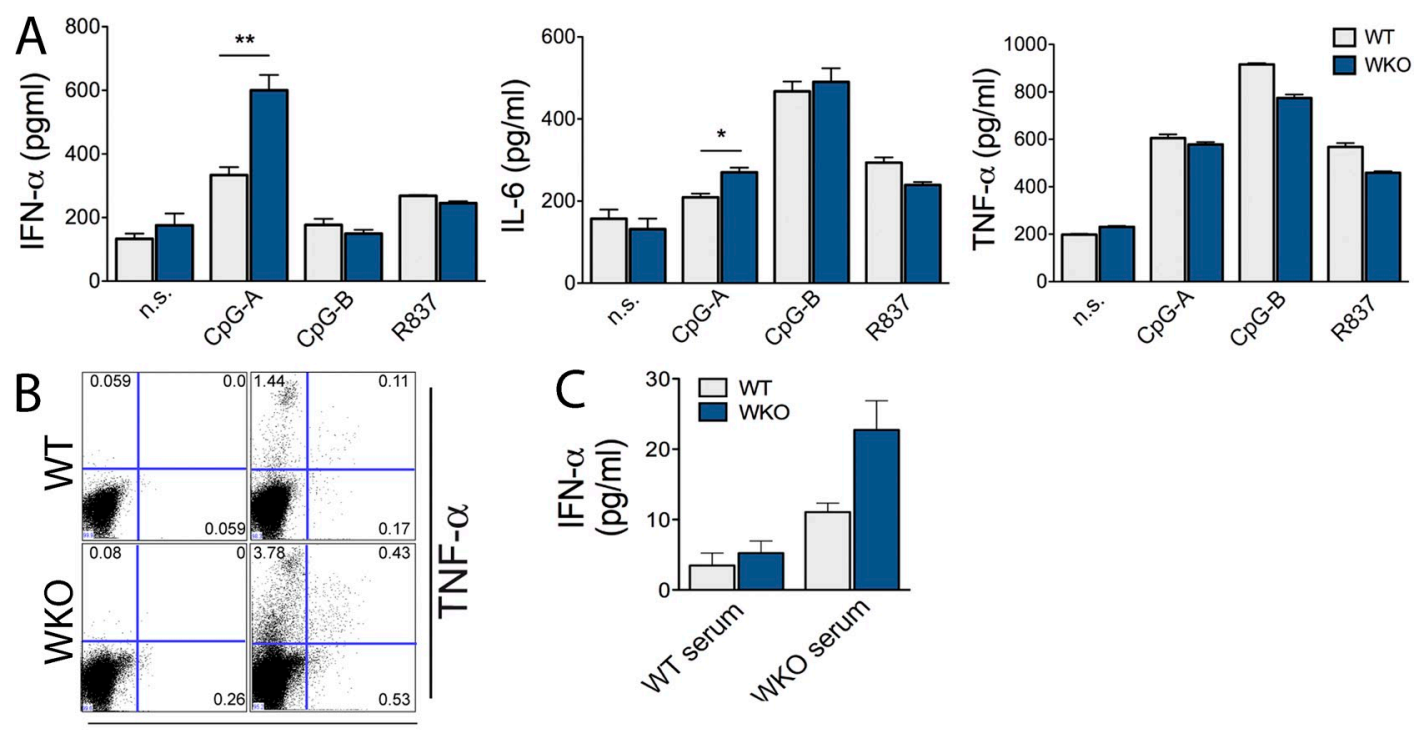

IFN- $\alpha$
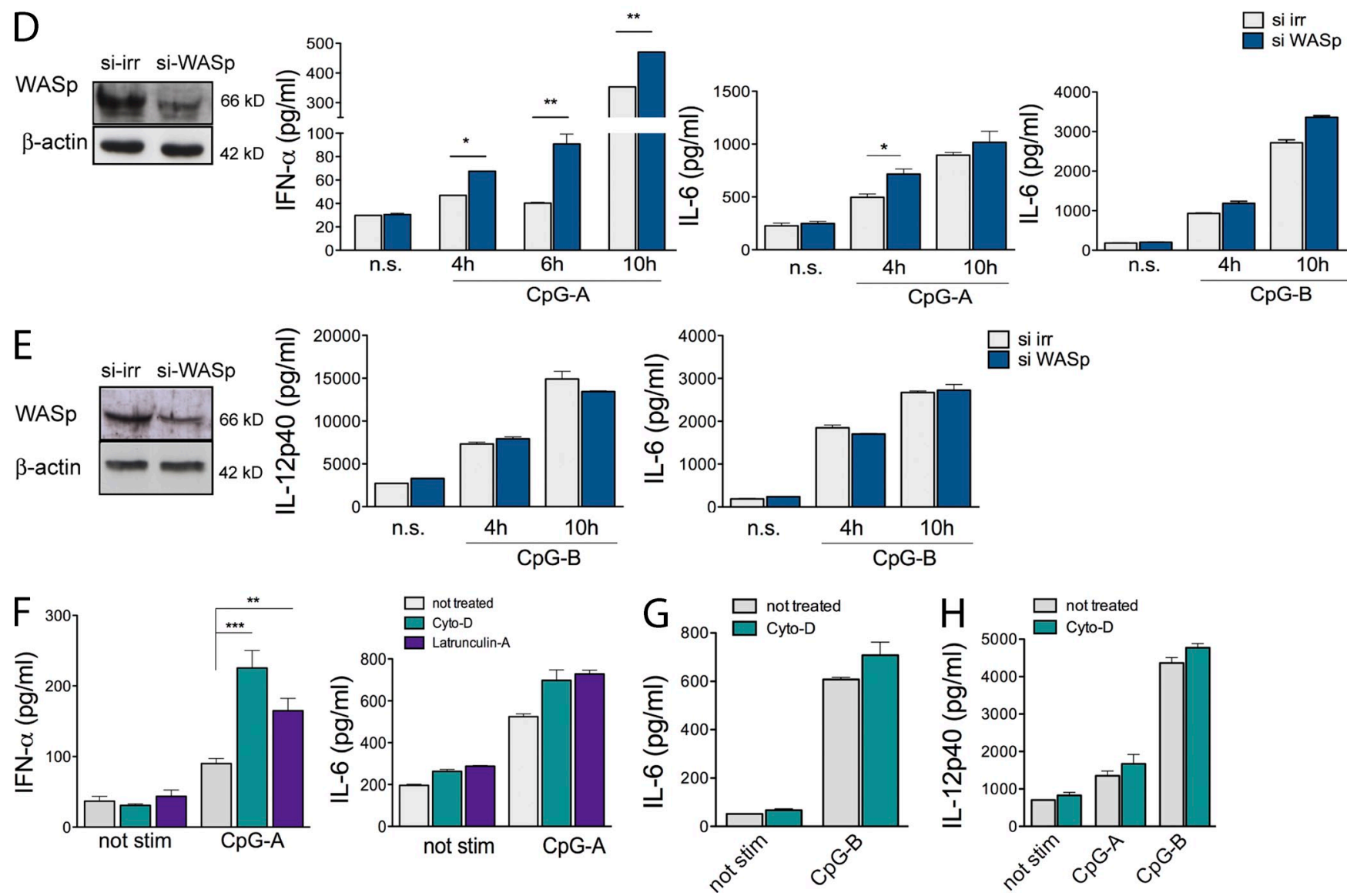

Figure 6. Cell-intrinsic role of WASp-mediated actin dynamics in limiting IFN- $\boldsymbol{\alpha}$ production in $\boldsymbol{p D C s}$. (A) Responses to TLR9 and TLR7 agonists in naive pDCs from young WKO mice. $3 \times 10^{5} \mathrm{pDCs}$ isolated from the spleen of young ( $\left.3 \mathrm{wk}\right)$ WT or WKO mice were stimulated ex vivo with $10 \mu \mathrm{g} / \mathrm{ml} \mathrm{CpG}-\mathrm{A}$ or CpG-B and $5 \mu \mathrm{g} / \mathrm{ml}$ R837. Bars show IFN- $\alpha$, IL-6, and TNF protein levels determined by ELISA in cell culture supernatant. Results are from two (R837) to five (CpG-A and CpG-B) independent experiments each with six mice per group. (B) pDCs were stimulated with $20 \mu \mathrm{g} / \mathrm{ml} \mathrm{CpG}-\mathrm{A}$ for $5 \mathrm{~h}$ in the presence of brefeldin A. Intracellular staining was performed with antibodies against IFN- $\alpha$ and TNF. The plots are from one representative experiment of three performed. (C) Splenic pDCs from young WT or WKO mice were incubated with sera from WT $(n=4)$ or WKO $(n=4)$ adult mice. Data show the levels of IFN- $\alpha$ in cell culture supernatants subtracted of the values in control wells without cells. Data are representative of two experiments with six mice per group. (D and E) BM-pDCs or BM-cDCs were nucleofected with siRNA control (si-irr) or WASp-specific (si-WASp) RNA oligos. (D) $3 \times 10^{5}$ control or WASp-silenced 

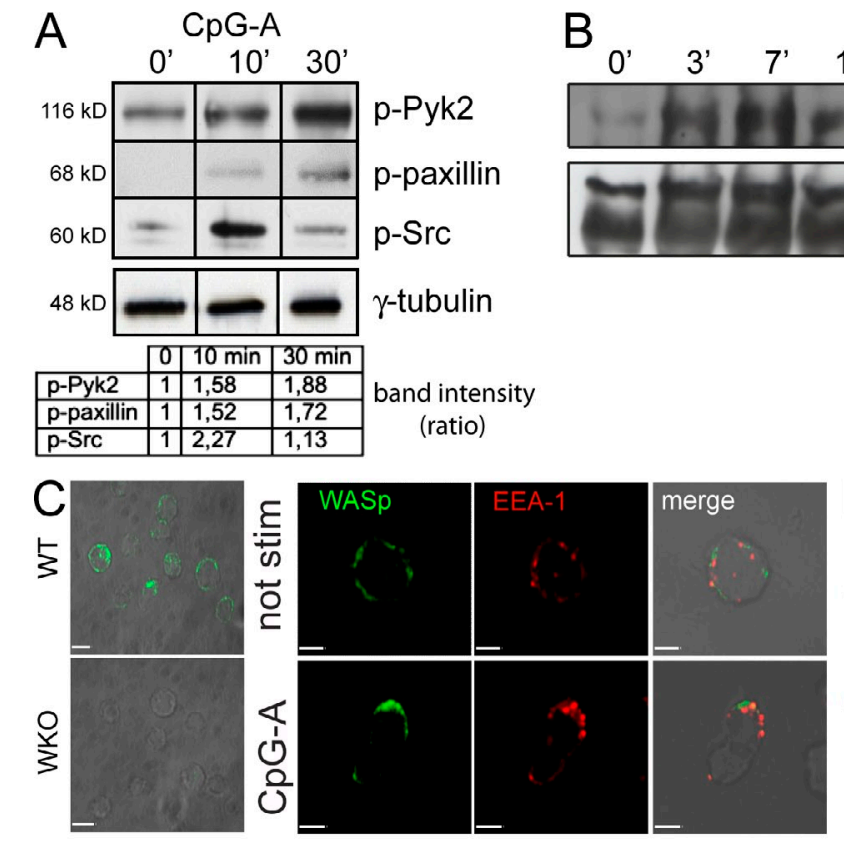
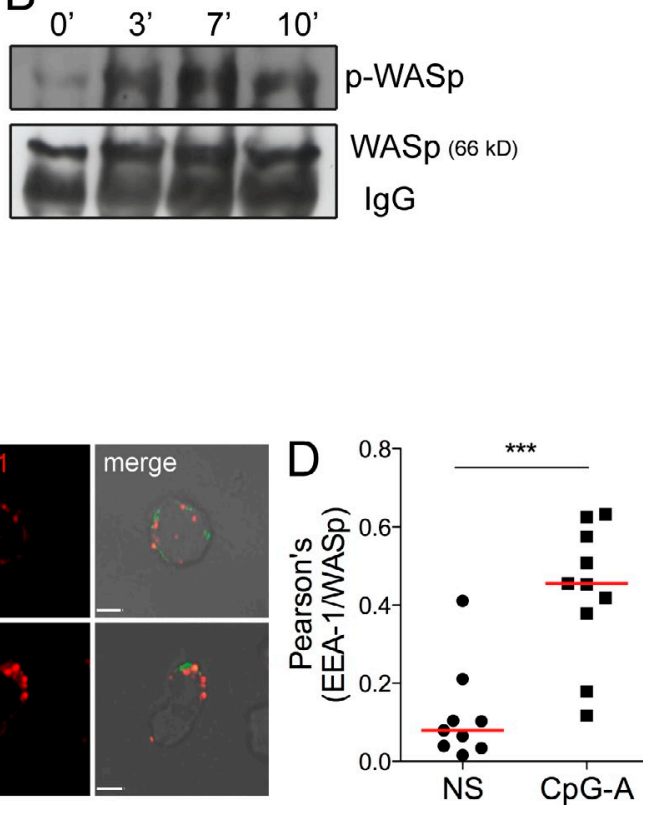

WASH, and cortactin are involved in EE fission and maturation into lysosomes (Derivery et al., 2009; Ohashi et al., 2011), we postulated that WASp might be involved in regulation of pDC activation by controlling delivery of TLR9 ligands within the endocytic pathway. To address this question, we first examined actin reorganization and WASp activation in WT pDCs. In agreement with previous observations in macrophages and myeloid DCs (Sanjuan et al., 2006), we found that $\mathrm{CpG}-\mathrm{A}$ induces phosphorylation of Src kinases and actin regulatory proteins such as paxillin and pyk2 (Fig. 7 A). Notably, stimulation with $\mathrm{CpG}-\mathrm{A}$ induced a rapid increase in WASp phosphorylation, a mechanism which was shown to be essential for WASp functions in several model systems but which has not been previously reported to be associated to TLR9 signaling (Fig. 7 B). Immunolabeling of WASp in pDCs was weak but specific and revealed a shifting from a diffuse cytoplasmic distribution in resting pDCs to accumulation of WASp in patches overlapping with EE upon CpGA stimulation, suggesting that WASp is involved in remodeling of endosomal actin during pDCs activation by TLR9 agonists (Fig. 7 C).

Next, we analyzed by confocal microscopy the fate of internalized CpG-A labeled with FITC in splenic pDCs isolated

Figure 7. CpG-A induces tyrosine phosphorylation of WASp and its localization in EE. (A) WT BM-pDCs were stimulated with $20 \mu \mathrm{g} / \mathrm{ml} \mathrm{CpG-A}$ and whole cell lysates were Western blotted with anti-phospho paxillin, anti-phospho Pyk2, and anti-phospho Src antibodies. (B) WT BM-pDCs were lysed after the indicated times of stimulation with $\mathrm{CpG}-\mathrm{A}$. WASp was immunoprecipitated from the cell lysates and the anti-WASp immunoprecipitates were Western blotted with anti total phospho-tyrosine and anti-WASp antibodies. (C) WT or WKO splenic pDC were labeled with antibodies against WASp to assess staining specificity (bars, far left panels, $33 \mu \mathrm{m}$ ). WT splenic pDCs from adult mice were left untreated or stimulated with CpG-A for 30 min, fixed, and labeled with antibodies against WASp and the EE marker EEA-1. Representative single confocal z-planes (middle) are shown. Bars, $3 \mu \mathrm{m}$. (D) The index of colocalization (Pearson's coefficient) between WASp and EEA- 1 staining was measured on 9 and 10 resting and stimulated cells, respectively. Red horizontal bars indicate the median. MannWhitney test. from young WT or WKO animals. EE in nonstimulated WT pDCs appeared as well defined rounded vesicles (mean EE volume $=3.3 \mu \mathrm{m}^{3} \pm 3.3 \mathrm{SD}$ ) distributed uniformly (Fig. $8 \mathrm{~A}$ ). In contrast, $\mathrm{EE}$ were often clustered in larger vesicles at one pole of the cells in resting WKO pDCs (mean EE volume = $5.24 \mu \mathrm{m}^{3} \pm 6 \mathrm{SD}$ ). Stimulation with $\mathrm{CpG}-\mathrm{A}$ FITC induced clustering of EE vesicles in areas of CpG-A uptake in both WT and WKO cells, resulting in an increase of EE volumes that was slightly higher in WKO cells. Remarkably, CpG-A vesicles inside WKO cells were larger and often displayed a tubular shape (Fig. 8, A and C). Quantitative analysis on 3D reconstructed images showed that intracellular $\mathrm{CpG}-\mathrm{A}$ vesicles have significantly larger volumes in WKO than in WT pDCs (Fig. 8 A). To establish that actin remodeling driven by WASp controls the compartmentalization of TLR 9 ligands in pDCs, we analyzed CpG-A vesicles in cells depleted of WASp expression by siRNA or treated with Cyto-D. The mean volume of the $\mathrm{CpG}-\mathrm{A}$-containing compartments was increased in both conditions, indicating that enhanced accumulation of TLR9 ligands is linked to stronger activation of IFN- $\alpha$ genes (Fig. 8 B). To better understand the nature of the CpG-A containing compartment, we quantified the colocalization of CpG-A FITC with markers of EE (EEA-1) and lysosomes (LAMP-1). At $1 \mathrm{~h}$

BM-pDCs were stimulated with $15 \mu \mathrm{g} / \mathrm{ml} \mathrm{CpG-A}$ or CpG-B. IFN- $\alpha$ and IL-6 protein levels were determined by ELISA. Results are from four experiments. (E) $3 \times 10^{5}$ control or WASp-silenced BM-cDCs were stimulated with $15 \mu \mathrm{g} / \mathrm{ml} \mathrm{CpG-B.} \mathrm{IL-12p40} \mathrm{and} \mathrm{IL-6} \mathrm{protein} \mathrm{levels} \mathrm{were} \mathrm{determined} \mathrm{by} \mathrm{ELISA.} \mathrm{Results}$ are representative of three experiments. (F) $3 \times 10^{5} \mathrm{BM}-\mathrm{pDCs}$ were preincubated with $1 \mu \mathrm{g} / \mathrm{ml}$ cytochalasin-D (Cyto-D), $0.1 \mu \mathrm{g} / \mathrm{ml}$ latrunculin-A or control medium, washed and stimulated with $5 \mu \mathrm{g} / \mathrm{ml} \mathrm{CpG-A}$ for $5 \mathrm{~h}$. Bars show concentrations of IFN- $\alpha$ and IL-6 protein in cell culture supernatants. Data are representative of two (latrunculin-A) to six (cytochalasin-D) independent experiments. Levels of IL-6 (G) and IL-12p40 (H) induced by CpG-B in Cyto-D-treated pDCs and Cyto-D-treated cDCs upon stimulation with $15 \mu \mathrm{g} / \mathrm{ml} \mathrm{CpG-A}$ and $\mathrm{CpG}-\mathrm{B}$, respectively. One representative experiment out of three with similar results is shown. $A, D$, and $E$, Student's $t$ test; $F$, Mann-Whitney test; error bars indicate $S E M .{ }^{*}, P<0.05{ }^{* *}, P<0.01{ }^{* * *}, P<0.001$. 

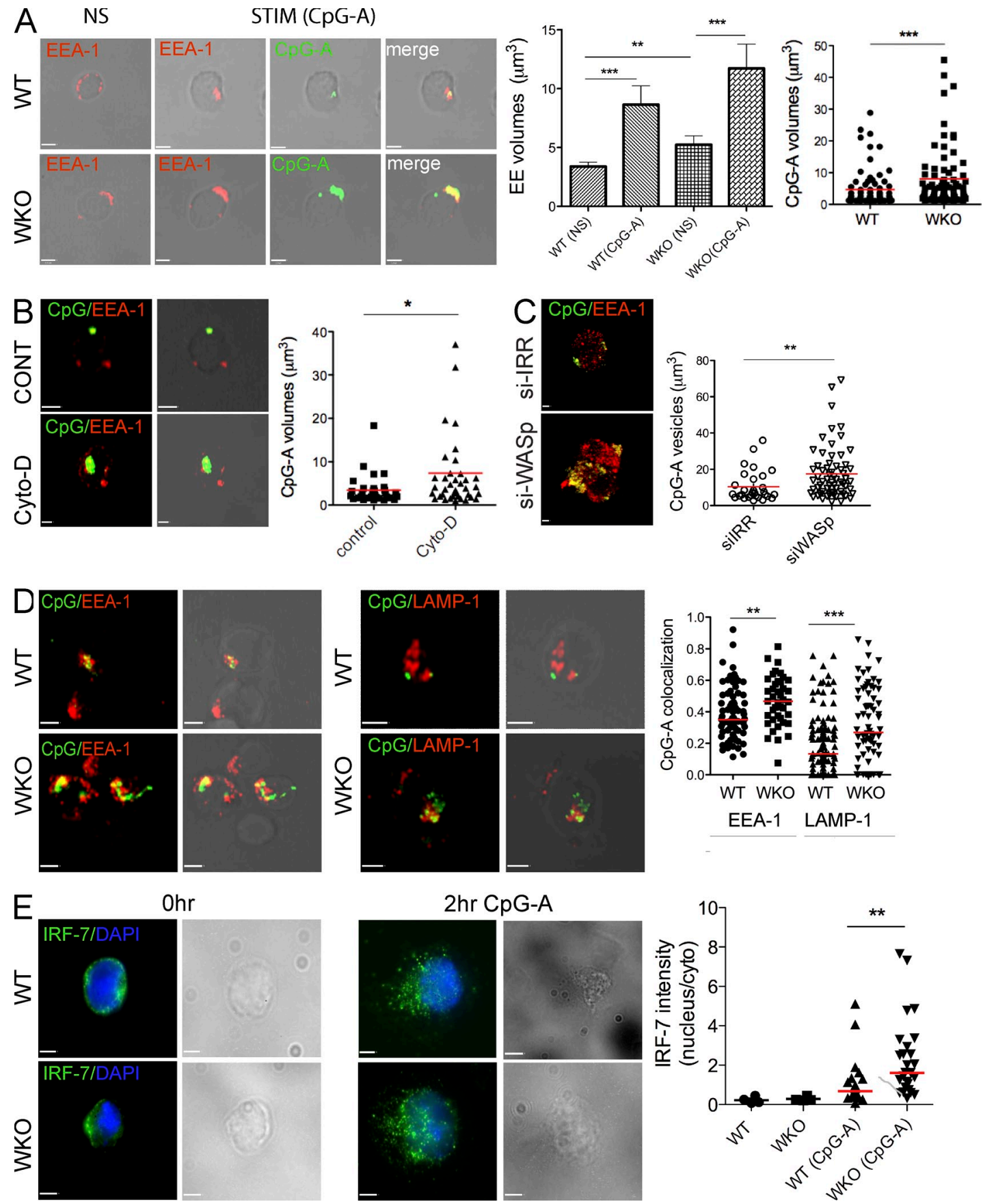

Figure 8. WASp controls CpG-A accumulation and EE size in pDCs. (A) Splenic pDCs from young WT and WKO mice were stimulated with $20 \mu g / m l$ CpG-A FITC for $30 \mathrm{~min}$ or left untreated (NS). Shown are representative confocal images of CpG-A and EEA-1 merged with DIC images. The quantification of EE volumes and CpG-A volumes on 3D reconstructed z-sections is shown on the right. For EE volumes, $n=85,19,63$, and 25 for WT(NS), WT(CpG-A), WKO(NS), and WKO(CpG-A), respectively. Mean and SEM are indicated, Mann-Whitney test. For CpG-A volumes, $n=74$ and $n=77$ cells were analyzed in WT and WKO, respectively. Horizontal bars show mean values. ${ }^{* *}, P=0.0008$, Mann-Whitney. (B) Splenic WT pDCs were pretreated with cytochalasin-D (or control medium) for $30 \mathrm{~min}$, washed, and exposed to CpG-A FITC for 30 min. Confocal images show representative example of CpG-A and EEA-1 staining merged with DIC images. The volume of intracellular CpG-A vesicles was quantified on $>30$ cells per condition. Bars show mean values, $P=0.034$, Mann-Whitney. (C) BM-PDCs treated with control or WASp-specific siRNA (si-IRR and si-WASp) were incubated with CpG-A-cy5 and immunostained with anti-EEA-1 antibodies. Representative single confocal planes are shown. The plot shows the quantification of CpG-A containing vesicles measured on 3D reconstructed images. Data were collected from 50 si-irr- and 50 si-WASp-treated cells. Horizontal bars show mean values. ${ }^{* *}, P=0.0021, M a n n-$ Whitney test. (D) Splenic pDCs isolated from young mice were incubated with $20 \mu \mathrm{g} / \mathrm{ml} \mathrm{CpG-A} \mathrm{FITC} \mathrm{for} 1 \mathrm{~h}$. Confocal images of CpG-A and EEA-1 (left) and LAMP-1 (right) staining merged with DIC images are shown. The graph represents Pearson's correlation coefficients that were calculated for $\mathrm{CpG}-\mathrm{A}$ and EEA-1 or CpG-A and LAMP-1 on 3D reconstituted z-sections. Data are from $n=74$ WT and $n=41$ WKO cells for EEA-1 ( $\left.{ }^{* *}, \mathrm{P}=0.0037\right)$, and from 
after uptake, CpG-A showed higher association with EE than with lysosome markers in both WT and WKO cells. However the index of $\mathrm{CpG}-\mathrm{A} / \mathrm{EE}$ colocalization was higher in WKO cells. Merging with lysosome markers was limited in WT pDCs (mean Pearson's coefficient $=0.18 \pm 0.018$ ), whereas it was significantly higher in WKO pDCs (mean Pearson's coefficient $=0.315 \pm 0.02$; Fig. $8 \mathrm{C}$ ). These data indicate that WKO pDCs accumulate larger amounts of intracellular CpG-A that are rapidly translocated to TLR 9 signaling compartments. We next quantified the nuclear translocation of IRF-7 in cells stimulated with CpG-A. IRF-7 staining was confined in the cytoplasm of nonstimulated cells and begun to accumulate in the nucleus at $2 \mathrm{~h}$ after activation. Quantitative analysis of nuclear/cytoplasmic IRF-7 fluorescence intensity revealed a higher ratio in stimulated WKO pDCs, indicating stronger nuclear recruitment. Thus, increased IFN- $\alpha$ production in WKO pDC is a result of enhanced signaling through the TLR9IRF-7 axis. Collectively, we conclude that lack of WASp in pDCs causes accumulation of large aggregates of multimeric TLR-9 ligands that rapidly traffic within the endocytic pathway leading to increased IRF-7 activation.

\section{Rescue of autoimmune manifestations in WASp null mice on an IFNAR-deficient background}

Finally, we directly examined whether dysregulated type-I IFN production plays a role in the pathogenesis of WAS autoimmune phenomena. To this purpose, we backcrossed WKO mice to mice lacking a functional IFN- $\alpha / \beta$ receptor (Prinz et al., 2008), referred to as DKO mice, hereafter. Ablation of type-I IFN signaling in WKO mice caused a significant reduction of splenomegaly and amelioration of colitis. As shown in Fig. 9 A, the total cellularity and spleen weight were increased in adult WKO mice with respect to WT mice, whereas they were comparable between WT and DKO mice. Consistent with previous reports (Snapper et al., 1998), 4-mo-old WKO mice develop colitis characterized by a dense mucosal $\mathrm{T}$ cell infiltration as measured on CD3-stained sections $\left(18.25 \mathrm{CD}^{+}\right.$cells/high power field $[\mathrm{HPF}]$ for WT vs. $58.25 \mathrm{CD}^{+}$cells/HPF for WKO, P $\left.<0.0001\right)$. In DKO, the density of infiltrating $\mathrm{T}$ cells was intermediate between WT and WKO (31.5 $\mathrm{CD}^{+}$cells/HPF) but still significantly different from the WT group (P < 001). Similarly, infiltrates of $\mathrm{B}$ and $\mathrm{T}$ cells in salivary glands were increased in WKO but almost absent in DKO animals (unpublished data).

Constitutive pDC activation and production of type-I IFN contribute to breach of peripheral tolerance through activation of $\mathrm{cDC}$, boosting their antigen-presenting capacity and secretion of proinflammatory cytokines (Blanco et al., 2001; Ding et al., 2006; Agrawal et al., 2009). We examined maturation and cytokine secretion in cDCs. In the absence of any stimulation, splenic WKO cDCs expressed significantly higher levels of maturation markers (CD40 and CD86) than WT cDCs, indicating a state of chronic activation. Expression in DKO cDCs was intermediate between WT and WKO, showing an almost complete rescue of spontaneous maturation. Moreover MHC-I expression was high in WKO cDCs but returned to WT level in cDCs isolated from DKO mice. Next, we stimulated cDCs with CpG-B or LPS to measure the production of proinflammatory cytokines. WKO cDCs produced increased levels of TNF, IL-12p40, and IL-6 as compared with WT cells. In contrast, secretion by DKO cells was significantly lower than in WKO cells and, for IL-6, even lower than in WT cells (Fig. 9 D). Thus, excessive maturation and responsiveness toTLR 4 and TLR9 in WKO cDCs depend on engagement of IFNAR. Secretion of $\mathrm{B}$ cell activating factor (BAFF) by IFN- $\alpha$-activated $\mathrm{cDCs}$ is a major mechanism by which DCs may amplify production of autoantibodies (Litinskiy et al., 2002; Cancro et al., 2009). The levels of BAFF in sera of WKO animals were indeed significantly higher than in WT mice, whereas they were completely rescued in DKO mice (Fig. 9 E). However, despite rescued BAFF levels, DKO mice still contained elevated anti-dsDNA antibodies, suggesting that cell-intrinsic B cell defects (Becker-Herman et al., 2011; Recher et al., 2012) are dominant over the contribution of the type-I IFN-BAFF axis (Fig. 9 F). Based on these data, we conclude that type-I IFN signaling in WAS promotes excessive activation of DCs and contributes to the development of autoimmune manifestations.

\section{DISCUSSION}

The mechanisms that limit unrestrained activation of innate immune cells upon ligation of pattern recognition receptors are of great interest, as it is increasingly recognized that failure to prevent excessive activation leads to chronic inflammation and autoimmunity. This work provides the first description of the role of WASp in pDCs, a crucial subset of innate immune cells specialized in secretion of type-I IFN. We show that type-I IFN production is negatively regulated by WASpdependent actin dynamics, both indirectly through cell extrinsic mechanisms and in a cell autonomous fashion. The combination of extrinsic and intrinsic cellular mechanisms leads to chronic pDC activation and spontaneous release of IFN- $\alpha$ that is involved in autoimmune disease. These findings provide a new important clue to understand the development of autoimmune phenomena in WAS and suggest the inclusion of the syndrome in the list of type-I IFN diseases.

pDCs are specialized in producing high levels of type-I IFNs upon recognition of foreign nucleic acid derived from endocytosed pathogens. In several type-I IFN diseases (SLE, Sjorgen, and psoriasis), unwanted pDC activation by self-nucleic acid

$n=116$ WT and $n=72$ WKO cells for LAMP-1 ${ }^{* * *}, P=0.0005$, Mann-Whitney $t$ test). Horizontal bars represent median. (E) Splenic pDCs from young mice were incubated with $10 \mu \mathrm{g} / \mathrm{ml} \mathrm{CpG-A}$ for $2 \mathrm{~h}$, fixed, and labeled with antibodies against IRF-7. Representative images are of resting and stimulated WT and WKO cells. The quantification shows the ratio between the mean fluorescence intensity in cytoplasm versus nucleus calculated on 4 and 25 resting and stimulated cells, respectively, in each group. Horizontal bars show mean values. ${ }^{*}{ }^{*}, \mathrm{P}=0.0017$, Mann-Whitney test. Bars, $3 \mu \mathrm{m}$. 

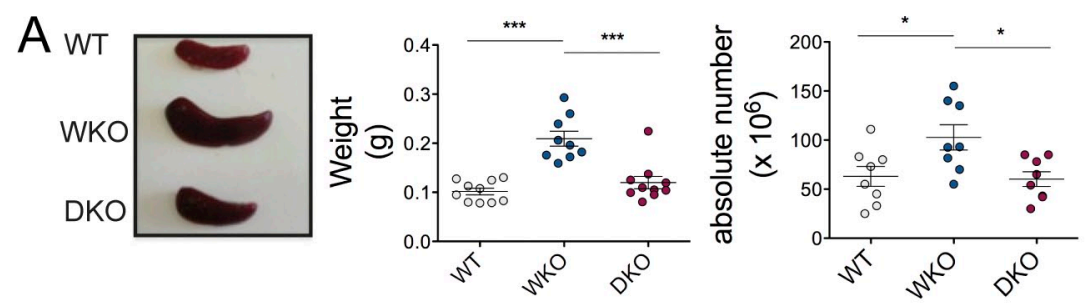

B
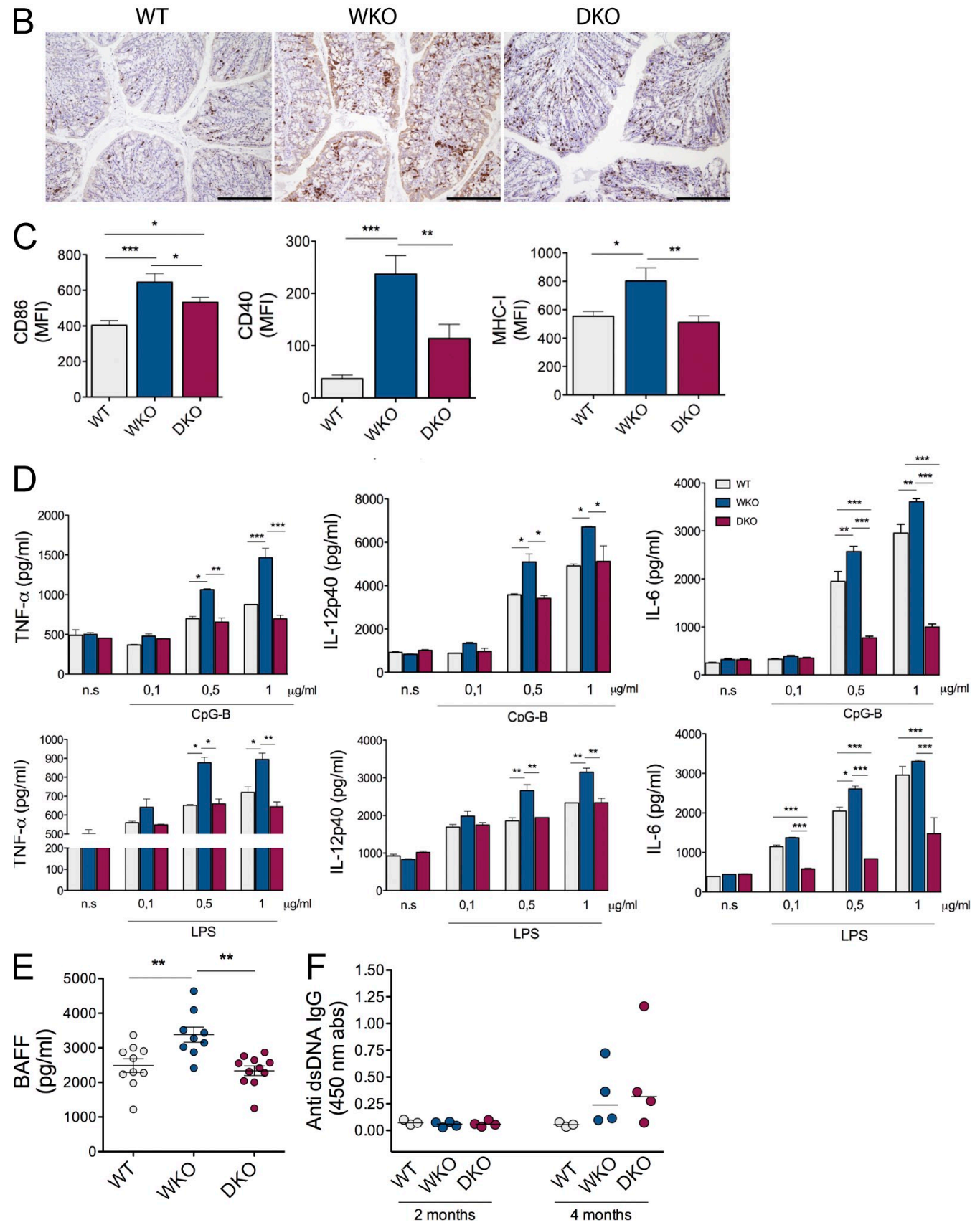

Figure 9. Partial rescue of autoimmune disease in IFNAR/WASp double KO mice. (A) Representative spleens from 3-mo-old WT, WKO, and DKO mice. Graphs represent spleen wet weight (in grams) and total splenocytes counts ( $n=7-10$ animals per group). (B) Formalin-fixed sections of large bowel are from 4-mo-old WT (left), WKO (middle), and DKO (right) mice and stained for anti-CD3. Compared with WT, WKO, and, to a lesser extent, DKO, show increased mucosal infiltration of $\mathrm{CD}^{+} \mathrm{T}$ cells. Sections are counterstained with Mayer's hematoxylin. Bar, $200 \mu \mathrm{m}$. (C) Mean fluorescence intensity (MFI) of CD86, CD40, and MHC-I expressed by cDC (CD11 $\mathrm{c}^{\text {hi) }}$ at steady state were measured by FACS in spleens of WT, WKO, and DKO mice. Data are from three independent experiments, each with two to four mice per group. (D) $3 \times 10^{5}$ WT, WKO, and DKO BM-cDCs were incubated with increasing doses of 
complexes has been recognized as a major pathogenetic mechanism (Vallin et al., 1999; Barrat et al., 2005; Gilliet and Lande, 2008; Gilliet et al., 2008). In the mouse model of WASp deficiency, we observed multiple signs of pDC activation, including an increased proliferation rate, higher expression of surface maturation markers, constitutive transcription of IFN- $\alpha$ genes, and elevated levels of systemic IFN- $\alpha$. Many evidences in WAS patients support the conclusion that elevated type-I IFN may contribute to disease pathogenesis. Analysis of gene expression on RNA isolated from PBMC of pediatric patients with a high clinical score showed upregulated expression of IFN- $\alpha$ genes and of several type-I inducible genes, as compared with normal donors, demonstrating exposure to elevated levels of this cytokine. Second, the sera from WAS patients, similarly to sera from SLE and JIA, induced release of IFN- $\alpha$ by normal pDCs. This indicates that the well documented pathogenic mechanism of chronic pDC triggering by endogenous factors is likely to operate also in WAS patients. In spite of this, we failed to detect consistent levels of IFN- $\alpha$ in sera, except from one patient with overt autoimmunity (unpublished data). Analysis of expression of MxA by immunohistochemistry on spleen sections of affected young boys confirmed elevated expression of this major target of type-I IFN in secondary lymphoid organs. We also report a reduced frequency of $\mathrm{pDCs}$ in the peripheral blood of our cohort of pediatric WAS patients. In this respect, the discrepancy with increased pDCs number observed in WKO mice may be explained by the exposure of WAS patients to repeated infections and corticosteroid treatment, two factors which can contribute to pDCs depletion (Duan et al., 2004; Kanto et al., 2004; Altfeld et al., 2011). Of note, total PBMC from WAS patients showed an increased IFN- $\alpha$ secretion when challenged with TLR 9 agonist. This finding is consistent with our observations in WASp null mouse pDCs (young prediseased mice and WASp silenced pDCs), strongly supporting that $\mathrm{pDCs}$ are basically hyperresponsive. It may be that blood-derived pDCs in PBMC, as opposed to splenic pDCs in mice, are just generated and have not yet been exposed to endogenous triggers, maintaining their naive responsiveness.

Indeed, we demonstrated a role for type-I IFN in the initiation of autoimmunity. WASp null mice made resistant to type-I IFN have milder disease in terms of splenomegaly, colitis, and salivary gland infiltrates. Our data suggest that IFN- $\alpha$ signaling diverts DCs toward a proinflammatory phenotype, which may directly contribute to development of colitis by inhibiting T reg cell proliferation (Murai et al., 2009). Consistent with this, a recent report showed a role for innate immune cells in inducing colitis in WASp null mice (Nguyen et al., 2012).Type-I IFN may also have direct effects in promoting proliferation of autoreactive B cells and $\mathrm{T}$ cells (Jego et al., 2003; Le Bon et al., 2006a,b). This is well illustrated in lupusprone mice models in which IFNAR deficiency invariably reduces the levels of autoantibodies (Santiago-Raber et al., 2003; Agrawal et al., 2009). Intriguingly, WASp mice deficient for IFNAR receptor, despite amelioration of others major autoimmune signs, still have elevated anti-dsDNA antibodies, indicating that both IFN-I-dependent and -independent pathways contribute to autoimmunity. Although further analyses are needed to characterize subclasses and specificity of autoantibodies in these mice, the data are consistent with a dominant cell intrinsic break in the B cell compartment in WAS (Becker-Herman et al., 2011; Recher et al., 2012).

We have identified two mechanisms that contribute to unabated pDCs activation in WASp-deficient animals. First, sera of WKO adult mice can induce IFN- $\alpha$ secretion, strongly suggesting that self-nucleic acids, in complex with autoantibodies (Humblet-Baron et al., 2007; Nikolov et al., 2010), are converted into pDCs inducers, similarly to what has been described in SLE (Barrat et al., 2005; Means et al., 2005). It is likely that other factors participate in $\mathrm{pDC}$ activation in $\mathrm{WKO}$, given that inefficient clearance of dying cells by macrophages (Lorenzi et al., 2000) is a source of endogenous TLR9 agonist (Båve et al., 2000). Chronic pDC activation in WASp mice caused a selective exhaustion of the IFN- $\alpha$ pathway. This selective effect may depend on consumption of specific factors in the Myd88-IRF-7 pathway or on the induction of negative regulators (Escoll et al., 2003). A similar inability of pDCs to make type-I IFN in response to a secondary challenge has already been described in the context of viral infections (Björck, 2004; Ito et al., 2006), in lupus-prone mice (Pau et al., 2012), and in SLE patients (Kwok et al., 2008a). Whether exhaustion of the IFN- $\alpha$ pathway is playing a role in inefficient viral clearance in WKO mice (Strom et al., 2003; Andreansky et al., 2005) will be a subject of future studies and it is certainly an important implication of our findings. Second and most compelling, we demonstrated with different approaches that WASp-deficient pDCs are inherently hyperresponsive to TLR9 triggering. Importantly, drug-induced inhibition of actin polymerization enhanced cytokine production, thus strengthening the notion that WASp restrains excessive activation via its actin regulatory properties. TLR9 signals through the adaptor protein MyD88 to activate two distinct pathways, one leading to the transcription of proinflammatory cytokines via $\mathrm{NF}-\kappa \mathrm{B}$ and the second leading to type-I IFN through IRF-7. Activation of these two different pathways depends on signaling from distinct endocytic organelles, with activation of IFN- $\alpha$ requiring access of TLR 9 to lysosome-like organelles (Honda et al., 2005; Sasai et al., 2010). Our functional studies show

CpG-B (top) or LPS (bottom). The levels of TNF, IL-12p40, and IL-6 were measured by ELISA in 4-h cell culture supernatants. Data are from two independent experiments, each with two to four mice per group. (E) The levels of BAFF were compared in the sera of WT $(n=10)$, WKO $(n=9)$, and DKO $(n=11)$ animals in absence of any prior stimulation. Error bars indicate SEM. Statistics were calculated by one-way ANOVA followed by Bonferroni's post hoc test. (F) Levels of IgG anti-dsDNA autoantibodies were evaluated by ELISA in sera from WT, WKO, and DKO mice at 2 and 4 mo of age ( $n=4$ mice per group). Horizontal bars show median. ${ }^{*}, \mathrm{P}<0.05 ;{ }^{* *}, \mathrm{P}<0.01 ;{ }^{* * *}, \mathrm{P}<0.001$. 
that $\mathrm{WKO} \mathrm{pDCs}$ isolated from young animals have a lower activation threshold for both pathways, but the effect on IFN- $\alpha$ production is more pronounced. Moreover, hyperresponsiveness is restricted to multimeric TLR 9 agonists that were shown to be retained into endosomes during activation of the MyD88-IRF-7 pathway (Honda et al., 2005). Our imaging studies revealed that perturbing actin dynamics in pDCs (by different approaches) invariably causes an increase in the size of the $\mathrm{CpG}-\mathrm{A}$-containing vesicles and that $\mathrm{CpG}-\mathrm{A}$ in WKO pDCs becomes associated to lysosomes more than in WT cells. Although we could not gain a dynamic picture of CpG-A trafficking in WKO pDCs, we propose that altered actin dynamics cause a slower or diverted progression along the endocytic pathway that favors assembly of the signaling cascade (especially the MyD88-IRF-7 branch, responsible for IFN- $\alpha$ activation). Alternatively, WASp may be required for the docking of negative regulators of TLR 9 signaling. Indeed, recent studies illustrated the role of actin during clathrin-mediated endocytosis (the pathway used by CpG-A to enter cells; Latz et al., 2004). WASp plays a central role in coordinating the action of several proteins, such as dynamin, myosins, membrane curvature proteins, cortactin, and intersectin, during the endocytic process (Cao et al., 2003; Itoh et al., 2005; Kaksonen et al., 2005; Merrifield et al., 2005; Takenawa and Suetsugu, 2007). Therefore, lack of WASp in pDCs may inhibit correct vesicle scission/fission/ sorting, or indirectly perturb the coordinated action of the remaining proteins that compete with WASp for upstream activators or downstream effectors. Interestingly, depletion of cortactin and actin depolymerizing drugs were shown to induce endosome enlargement and tubulation similarly to what we observed in WKO cells (Itoh et al., 2005; Ohashi et al., 2011). It would be interesting to evaluate whether the increased responses to TLR 9 triggering recently reported in WASp null B cells (Becker-Herman et al., 2011) are linked to similar alterations of the endocytic pathway. In conclusion, this study adds a new layer of complexity to our understanding of the pathophysiology of this disease and raises important considerations about the treatment of patients with autoimmune phenomena. Finally, the implications of this study go beyond the pathophysiology of WAS, introducing actin as a new player in the complex scenario of the negative regulation of IFN- $\alpha$ production in $\mathrm{pDCs}$.

\section{MATERIALS AND METHODS}

Patients and tissues. The occurrence, frequency, and distribution of PDC were studied on formalin-fixed paraffin-embedded spleen sections from patients affected by WAS or XLT (11 cases) and obtained from the archive of the Department of Pathology, Spedali Civili di Brescia. Clinical and molecular data were provided for each case (Department of Pediatrics, Institute of Molecular Medicine "A. Nocivelli," University of Brescia, Brescia, Italy) and previously described in Wengler et al. (1995), Vermi et al. (1999), and Jin et al. (2004). Normal spleen from agematched control patients (10 cases) who underwent splenectomy for trauma or spherocytosis were used for comparison. Peripheral blood samples were collected according to the protocol for research studies on biological material from patients with primary immunodeficiency (TIGET 02), including WAS, approved by the HSR Institutional Ethical Committee.
Biological specimen from HDs (children) were collected and used upon informed consent for research purpose in agreement with the rules defined by approved protocols TIGET PERIBLOOD. For pDC isolation, $\mathrm{CD}^{+}, \mathrm{CD} 14^{+}, \mathrm{CD} 15^{+}, \mathrm{CD} 19^{+}$, and $\mathrm{CD} 56^{+}$cells were depleted from PBMCs using magnetic beads (Miltenyi Biotec). CD3 ${ }^{-/ C D} 14^{-} / \mathrm{CD} 15^{-/}$ $\mathrm{CD}^{-} / \mathrm{CD}^{-} 6^{-}$cells were stained with PE-conjugated anti-BDCA-2 (Miltenyi Biotec), and BDCA-2 ${ }^{+}$cells were isolated using anti-PE magnetic beads (Miltenyi Biotec).

Immunohistochemistry. 4- $\mu \mathrm{m}$ formalin-fixed paraffin-embedded tissue sections were stained with anti-BDCA2 (mouse IgG1, clone 124B3.13, dilution 1:50; Dendritics), and anti-MxA (mouse IgG2a, dilution 1:500, provided by O. Haller, University of Freiburg, Freiburg, Germany). Epitope retrieval was obtained by microwave heating in EDTA buffer, $\mathrm{pH}$ 8.0, for $3 \times 5 \mathrm{~min}$, at $750 \mathrm{~W}$ for anti-MxA and for $2 \times 5 \mathrm{~min}$ at JET and $3 \times 5 \mathrm{~min}$ at $750 \mathrm{~W}$ for anti-CD303. Reactivity was revealed using the EnVision antimouse HRP-linked detection kit (Dako) for anti-MXA or Bond Polymer Refine Detection (Leica) for anti-BDCA2 followed by DAB. Distribution of PDC was analyzed by double immunohistochemistry using primary antibody to BDCA2 and CD3 (rabbit, clone SP7, dilution 1:100; Thermo Fisher Scientific). After completing the first immune reaction against BDCA2, the second immune reaction was visualized using Mach 4 MR-AP (Biocare Medical), followed by Ferangi Blue (Biocare Medical) as chromogen. Absolute PDC count was quantified automatically applying a custom-programmed script in Cognition Network Language based on the Definiens Cognition Network Technology platform (Definiens AG). In brief, digital slides of entire spleen sections immunostained for CD303 were obtained by Aperio ScanScope CS Slide Scanner (Aperio Technologies) at $40 \times$ magnification and analyzed using Tissue Studio 2.0 (Definiens AG). The quantitative scoring algorithm for BDCA2 was customized by using commercially available templates. The algorithm was created to match the requirements of the CD303 staining parameter in human spleen and includes Manual ROI Selection (Draw Polygon). PDCs are expressed as number of CD303-positive cells $/ \mathrm{mm}^{2}$ of spleen area. Spleen MxA expression was scored as percentage of positive cells: positivity score $1=<25 \%$ of positive cells; score $2=25-50 \%$ of positive cells; score $3=>50 \%$ of positive cells; score $4=>75 \%$ of positive cells. As an additional strategy, we also measured total MxA signal by Tissue Studio 2.0 (Definiens AG) on spleen digital slides immunostained for MxA. The algorithm was created to match the requirements of the MxA staining parameter in spleen sections and includes Manual ROI Selection (Draw Polygon). Data are expressed as percentage of spleen area immunostained for $\mathrm{MxA}$.

For figure panel preparation, immunostained sections were photographed using a digital camera (DP-70; Olympus) mounted on a microscope (BX60; Olympus) and processed using Analysis Image Processing software (Olympus). Scoring of the T cell infiltration was performed on formalin-fixed paraffin-embedded sections of mice large bowel. 4- $\mu \mathrm{m}$ sections were stained with anti-CD3 (rabbit monoclonal, clone SP7, dilution 1:100; Thermo Fisher Scientific). Antigen retrieval was obtained by microwave heating in EDTA buffer, $\mathrm{pH} 8.0$, for $3 \times 5 \mathrm{~min}$ at $750 \mathrm{~W}$, and reactivity was revealed using EnVision HRP-linked detection system (Dako) followed by diaminobenzidine (DAB). Nuclei were counterstained with hematoxylin. $T$ cells were quantified on at least $10 \mathrm{HPF} /$ mouse.

Analysis of pDC frequency in human peripheral blood. Immunophenotyping of human pDCs was performed using the following anti-human antibodies: APC-conjugated anti-CD3/anti-CD14/anti-CD15/anti-CD16/ anti-CD19/anti-CD20/anti-CD56 (lineage cocktail; BD); PE-conjugated anti-BDCA-2 (Miltenyi Biotec); and PE-Cy7-conjugated anti-CD4 (BD; Presicce et al., 2008). The pDC subset was identified as lineage cocktailnegative/BDCA-2 $2^{+} / \mathrm{CD} 4^{+}$cells gated on live cells. Stained cells were acquired with a FACS CANTO flow cytometer and analyzed with FCS Express software (version 2.3; De Novo Software). Isotype controls were performed with corresponding mouse Ig. 
IFN- $\boldsymbol{\alpha}$ induction. $5 \times 10^{5}$ PBMCs were stimulated using $5 \mu \mathrm{M}$ CpG ODN 2216 (Enzo Life Sciences) in 96-well plates at a final volume of $200 \mu \mathrm{l} /$ well Afterward, 24 supernatants were collected and stored at $-80^{\circ} \mathrm{C}$. For IFN- $\alpha$ induction in pDCs by serum, $2 \times 10^{5} \mathrm{BDCA}-2^{+}$cells were incubated with $50 \%$ serum at a final volume of $200 \mu \mathrm{l} /$ well. Afterward, 24 supernatants were collected and stored at $-80^{\circ} \mathrm{C}$. The amount of IFN- $\alpha$ was measured in the supernatant by ELISA (Verikine Human IFN Alpha Serum Sample ELISA kit; PBL InterferonSource).

Analysis of gene expression profile in PBMCs. mRNA was extracted from PBMCs of WAS patients and HDs using RNeasy Mini kit (QIAGEN). Retrotranscription was performed using the $\mathrm{RT}^{2}$ First Strand kit (SABiosciences). Real-time PCR on cDNA samples was performed according to the protocol provided with the kit (Human IFN- $\alpha,-\beta$ Response PCR Array; SABiosciences) on aViiA 7 Real-Time PCR System (Life Technologies). $\Delta$ Ct values were calculated for each target gene by normalizing the $\mathrm{Ct}$ value of the target gene to the $\mathrm{Ct}$ value of the housekeeping gene. $\Delta \Delta \mathrm{Ct}$ values were calculated for each target gene by normalizing the WAS patient $\Delta \mathrm{Ct}$ value to the mean $\Delta \mathrm{Ct}$ value of the same gene expressed by healthy controls. Fold increase values were calculated for each target gene using the following formula: $2^{(-\Delta \Delta \mathrm{C} t)}$.

Mice. WASp ${ }^{-/}$(WKO) mice on a C57BL/6 (CD45.2) genetic background were a gift from S. Snapper (Massachusetts General Hospital, Boston, MA). Mice were bred and maintained in sterile isolators. In vivo experiments were performed using $\mathrm{WASP}^{-/-}$homozygous female or $\mathrm{WASp}^{-}$male as WKO and WT littermate as control. Mice lacking the $\alpha$-chain of the IFN- $\alpha / \beta$ receptor on a B6 background were provided by $U$. Kalinke and bred with the WASp ${ }^{-/-}$mice to generate $\mathrm{IFNAR}^{-1-} / \mathrm{WASp}^{-/-}$ double $\mathrm{KO}(\mathrm{DKO})$ mice. Animal care and treatment were conducted in conformity with institutional guidelines in compliance with national and international laws and policies (European Economic Community Council Directive 86/609; OJL 358; December 12, 1987). Protocols were approved by the Italian Ministry of Health.

Cells. BM-derived $\mathrm{pDCs}$ and $\mathrm{cDCs}$ were differentiated in vitro from the BM of WT or WASp KO mice using FLT-3 ligand. DCs were used for experiments between days 6 and 8 . BM-pDC and BM-cDC were obtained by positive and negative selection, respectively, using $\mathrm{B} 220^{+}$microbeads (Miltenyi Biotec). For isolation of $\mathrm{pDCs}$ from organs, cell suspension were obtained by digestion with $1.6 \mathrm{mg} / \mathrm{ml}$ collagenase D (Roche) and $0.1 \mathrm{mg} / \mathrm{ml}$ DNase I (Roche) for $30 \mathrm{~min}$ at $37^{\circ} \mathrm{C}$. Splenic pDCs were enriched from total spleen cells using the Plasmacytoid Dendritic Cell Isolation kit II, mouse (Miltenyi Biotec). In some experiments, CD11 $\mathrm{c}^{+} / \mathrm{PDCA}-1^{+} / \mathrm{B} 220^{+}$cells were isolated from $\mathrm{B}$ and $\mathrm{T}$ cell-depleted spleen cells or total lymph node cell suspensions using a FACSAria III cell sorter (BD). Purity was higher that 95\%.

TLR agonists. The CpG-A (1585) and CpG-B (1826) oligonucleotides and R837 were from InvivoGen. The Cy5-labeled CpG-A was obtained from Sigma-Aldrich. FITC-CpG-A was from InvivoGen. The lipopolysaccharide (Escherichia coli O55:B5) was from Enzo Life Sciences.

In vivo treatment. Mice were injected in the tail vein with $\mathrm{CpG}-\mathrm{A}$ complexed with the cationic lipid 1,2-dioleoyloxy-3-trimethylammonium-propane (DOTAP). For preparation of CpG-A/DOTAP mixture, $10 \mu \mathrm{g}$ CpG-A resolved in $50 \mu \mathrm{l}$ PBS was incubated with $30 \mu \mathrm{l}(30 \mu \mathrm{g})$ DOTAP Liposomal Transfection Reagent (Roche) in a polystyrene tube containing $70 \mu \mathrm{l}$ PBS for 15 $\mathrm{min}$ at room temperature. $150 \mu \mathrm{l}$ of the $\mathrm{CpG}-\mathrm{A} / \mathrm{DOTAP}$ mixture was then injected. Sera were collected 2, 6, 10, and $24 \mathrm{~h}$ after the CpG-A/DOTAP injection and analyzed for the content of IFN- $\alpha$, IL-6, and IL-12p40. For the detection of intracellular IFN- $\alpha$, spleens are collected $45 \mathrm{~min}, 2 \mathrm{~h}$, and $30 \mathrm{~min}$ or $6 \mathrm{~h}$ after the injection. Cytokine ELISA kits were purchased from PBL Biomedical Laboratories (IFN- $\alpha$ ) and Thermo Fisher Scientific (IL-12p40 and IL-6).

BrdU incorporation. For continuous in vivo BrdU labeling, mice were fed $1 \mathrm{mg} / \mathrm{ml} \mathrm{BrdU}$ (Sigma-Aldrich) in 10\% sucrose-supplemented drinking water for $7 \mathrm{~d}$ and then sacrificed. BrdU incorporation in spleen, lymph node, and BM cells was determined using the FITC BrdU flow kit (BD). For cell death analysis, splenocytes stained with antibodies to CD11c, B220, and PDCA-1 were labeled with FITC-conjugated annexin V and 7-amino-actinomycin D (7-AAD; BD). Dead cells were defined as 7-AAD ${ }^{+}$ cells and apoptotic cells as 7-AAD ${ }^{-}$annexin $\mathrm{V}^{+}$.

FACS analysis. The following Abs for FACS analysis were purchased from BioLegend: PE-conjugated Sca-1; PE-Cy7-, FITC-, and PE-conjugated anti-CD11c; FITC- and PE-Cy5-conjugated anti I-A ${ }^{\mathrm{b}}$; PE- and PECy5-conjugated anti-CD86; PE-Cy5-conjugated anti-CD40; PE- and FITC-conjugated anti-B220; FITC- and APC-conjugated anti-PDCA-1; PE-Cy5-conjugated anti-CD19; FITC- and APC-conjugated anti-CD3; and PE-Cy7-conjugated anti-TNF. Anti-IFN- $\alpha$ RMMA-1 was from PBL Biomedical Laboratories, Inc. FITC-conjugated anti-WASp was purchased from Santa Cruz Biotechnology, Inc. For analysis of number and activation of pDCs, total cells freshly isolated from spleen, lymph nodes, and blood were stained for $30 \mathrm{~min}$ at $4^{\circ} \mathrm{C}$ with antibodies to extracellular markers CD11c, B220, and PDCA-1 for the detection of pDC subset and with antibodies to CD86, CD40, or I- $\mathrm{A}^{\mathrm{b}}$ for the analysis of the maturation state. Stained cells were acquired with a FACSAria III flow cytometer and analyzed with FLOWJO software (version 4.5.4; Tree Star). Isotype controls were performed with corresponding rat Ig. For detection of intracellular IFN- $\alpha$ in splenic pDCs, $10 \mu \mathrm{g} / \mathrm{ml}$ Brefeldin A (Sigma-Aldrich) was added during all the phases of DC enrichment procedure and staining. Cells were enriched from total spleen cells by depletion of $\mathrm{B}$ and $\mathrm{T}$ cells and stained for extracellular markers using antibodies to CD11c, B220, and PDCA-1. Cells were then processed with the Fix \& Perm kit (BD) according to the manufacturer's instructions and then stained overnight at $4^{\circ} \mathrm{C}$ with an anti-IFN- $\alpha$ antibody. For detection of intracellular IFN- $\alpha$ and TNF by BM-pDC, cells were stimulated with $20 \mu \mathrm{g} / \mathrm{ml} \mathrm{CpG-A}$ for $5 \mathrm{~h}$ at $37^{\circ} \mathrm{C}$ in the presence of $10 \mu \mathrm{g} / \mathrm{ml}$ Brefeldin A. Cells were processed with the Fix \& Perm kit and then stained over night at $4^{\circ} \mathrm{C}$ with anti-IFN- $\alpha$ and anti-TNF antibodies.

RNA extraction and real-time polymerase chain reaction. Total RNA from isolated endogenous pDCs of pooled mice $(n=4)$ was prepared with TRIzol (Invitrogen) and treated with DNase I (Fermentas) according to the manufacturer's protocol. cDNA was synthesized with random hexamers and M-MLV reverse transcription (Invitrogen). Quantitative real-time PCR analysis was performed with the CFX96 Touch Real-Time PCR Detection System and iQ SYBR green Supermix (Bio-Rad Laboratories). $\beta$-actin mRNA was used for normalization of Ifn $\alpha 4$ and Il6 mRNA expression. Primer sequences were as follows: IFN- $\alpha 4$ forward, $5^{\prime}$-CCTGTGTGATGCAGGAACC-3' , and reverse, 5' -TCACCTCCCAGGCACAGA-3'; IL-6 forward, 5'-GAGGATACCACTCCCAACAGA-3', and reverse, 5'-AAGTGCATCATCGTTGTTCAT- $3^{\prime} ; \beta$-actin forward, $5^{\prime}$-CAGAAGGAGATTACTGCTCTGGCT-3' and reverse, 5'-GGAGCCACCGATCCACACA-3'. Thermal cycle conditions were the following: $95^{\circ} \mathrm{C}$ for $3 \mathrm{~min}, 43$ cycles of $95^{\circ} \mathrm{C}$ for $10 \mathrm{~s}$, and $60^{\circ} \mathrm{C}$ for $30 \mathrm{~s}$. Each sample was analyzed in duplicates, and the relative expression of target genes were defined by calculating the $\Delta$ cycle threshold, with respect to the housekeeping gene.

Silencing of WASp. ONE-TARGET plus siRNA targeting WASp and ONE-TARGETING plus nontargeting siRNA (Thermo Fisher Scientific; Dharmacon RNAi Technology) and used as specific WASp siRNA and as control siRNA, respectively. $8 \times 10^{6} \mathrm{BM}$-pDCs or -cDCs were transfected with $10 \mu \mathrm{M}$ siRNA using the Nucleofector (Amaxa) according to the manufacturer's instructions. Cells were collected $48 \mathrm{~h}$ after transfection. To assess depletion of WASp, $3 \times 10^{5}$ cells were lysed and analyzed by SDS page using anti-WASp antibody (Santa Cruz Biotechnology, Inc.). Protein reduction was assessed by ImageJ (National Institutes of Health).

Cytochalasin-D and latrunculin-A treatment. BM-pDCs and -cDCs were plated in 96-well culture plates in complete medium including $1 \mu \mathrm{g} / \mathrm{ml}$ cytochalasin D (Sigma-Aldrich) or $0.1 \mu \mathrm{M}$ latrunculin-A (AdipoGen) for 
$20 \mathrm{~min}$ at $37^{\circ} \mathrm{C}$. Cells were washed two times and incubated in complete medium containing the TLR ligands for $5 \mathrm{~h}$ at $37^{\circ} \mathrm{C}$. Culture supernatants were collected for ELISA analysis.

Functional in vitro assays. Splenic pDCs isolated by sorting or by magnetic beads were washed, resuspended in complete IMDM supplemented with Flt3 ligand, and cultured in 96-well culture plates for different time points at $37^{\circ} \mathrm{C}$ in the presence of CpG-A, CpG-B (10-15 $\left.\mu \mathrm{g} / \mathrm{ml}\right)$, or R837 $(5 \mu \mathrm{g} / \mathrm{ml})$. Culture supernatants were collected for ELISA analysis. Cell pellets were lysed to extract RNA for qRT-PCR. BM-cDCs from WT, WKO, and DKO animals were resuspended in complete IMDM and cultured in 96-well culture plates for $4 \mathrm{~h}$ at $37^{\circ} \mathrm{C}$ in the presence of different doses of CpG-B or LPS. Culture supernatants were collected for ELISA analysis. Silenced BM-pDCs and -cDCs were washed, resuspended in complete IMDM supplemented with Flt3 ligand, and cultured in the presence of CpG-A or CpG-B at $15 \mu \mathrm{g} / \mathrm{ml}$ for different time points. Culture supernatants were collected for ELISA analysis after $8 \mathrm{~h}$. To test IFN-I production by mice sera, BM-pDCs were resuspended in complete IMDM supplemented with Flt3 ligand and cultured in the presence of 1:5 dilution of sera. Cell pellets were lysed to extract RNA after $5 \mathrm{~h}$. Culture supernatants were collected for ELISA analysis overnight.Values obtained in control wells (diluted sera without cells) were subtracted from experimental wells to quantify de novo production by pDCs. Treatment with DNase was performed as follows: DNase I (Fermentas) was dissolved in IMDM at $200 \mu \mathrm{g} / \mathrm{ml}$ and $50 \mu \mathrm{l}$ of serum was incubated with an equal volume of PBS containing $10 \mu \mathrm{g}$ DNase and $0,3 \mu \mathrm{mol} \mathrm{MgCl}_{2}$ for $1 \mathrm{~h}$ at $37^{\circ} \mathrm{C} .5 \mu \mathrm{l}$ of $50 \mathrm{mM}$ EDTA was added to stop the enzyme reaction. Control sera were incubated with IMDM containing no DNase.

Antinuclear antibody and BAFF detection. NIH $3 \mathrm{~T} 3$ cells were grown on glass coverslips in 35-mm dishes. After $1 \mathrm{~d}$ in culture at $60 \%$ confluence, the cells were washed with PBS and then fixed for $20 \mathrm{~min}$ at room temperature with $4 \%$ paraformaldehyde in PBS. The fixed cells were permeabilized by exposure to $1 \%$ Triton X-100 in PBS for $5 \mathrm{~min}$, washed, and incubated with blocking buffer (PBS-2\%BSA) for $1 \mathrm{~h}$ at room temperature. Cells were then stained with sera collected from indicated mice (diluted 1:40 in PBS) for $1.5 \mathrm{~h}$, followed by incubation with FITC-conjugated goat anti-mouse IgG antibody for $1 \mathrm{~h}$ (Sigma Aldrich). Cells were subsequently washed, stained with DAPI, and the coverslips were mounted on the slides. For detection of anti-dsDNA autoantibodies by ELISA, 96-well Immuno-Plates (Nunc) were coated with $0.01 \%$ poly-L-lysine solution in PBS (SigmaAldrich) for $1 \mathrm{~h}$ at room temperature, and then incubated overnight with $10 \mathrm{mg} / \mathrm{ml}$ plasmid DNA in borate buffer saline, $\mathrm{pH}$ 8.4. After blocking with $0.5 \% \mathrm{BSA} / \mathrm{PBS}$ for $3 \mathrm{~h}$ at room temperature, serially diluted serum samples in $0.05 \%$ Tween $20 / 0.5 \%$ BSA/PBS were added to the plates in duplicate and incubated for $2 \mathrm{~h}$ at room temperature. Plates were then washed with $0.05 \%$ Tween 20/PBS and goat anti-mouse IgG HRP (Cell Signaling Technology) diluted at 1:2,000 into $0.05 \%$ Tween $20 / 0.5 \%$ BSA/PBS was added to each well. Peroxidase reactions were developed using TMB Peroxidase EIA Substrate (Bio-Rad Laboratories) and stopped with $0.2 \quad \mathrm{~N} \mathrm{H}_{2} \mathrm{SO}_{4}$. OD450 was read using MRX Microplate Reader (DYNEX technologies). Serum levels of BAFF were determined using Quantikine ELISA kit mouse BAFF/BLys/TNFSF13B (R\&D Systems). Serum anti-dsDNA IgG were assessed by ELISA.

In vitro phosphorylation of Pyk2, paxillin, and Src kinases. $5 \times 10^{5}$ WT BM-pDCs were resuspended in complete IMDM supplemented with Flt3 ligand and incubated with CpG-A at $10 \mu \mathrm{g} / \mathrm{ml}$ for 10 or $30 \mathrm{~min}$ at $37^{\circ} \mathrm{C}$. Cells were washed and lysed with NP-40 plus phosphatase inhibitors $(20 \mathrm{mM}$ Tris- $\mathrm{HCl}, \mathrm{pH}$ 7.4, $150 \mathrm{mM} \mathrm{NaCl}, 1 \mathrm{mM}$ EDTA, $1 \mathrm{mM}$ DTT, $1 \%$ Nonidet P-40, $1 \mathrm{mM}$ sodium orthovanadate, $10 \mathrm{mM} \mathrm{NaF}$, and Protease Inhibitor Cocktail). Total lysates were analyzed by SDS-PAGE (NuPAGE 4-12\% Bis-Tris gradient gels; Invitrogen) and immunoblotted with the antibodies specific for phospho-Pyk2 (Tyr-402), phospho-paxillin (Tyr-118), and phospho-Src family (Tyr-416), all provided by Cell Signaling Technology.
Immunoprecipitation of WASp. $8 \times 10^{6}$ WT BM-DCs were resuspended in complete IMDM supplemented with Flt3 ligand and incubated with CpG-A at $20 \mu \mathrm{g} / \mathrm{ml}$ for 3,7 , or $10 \mathrm{~min}$ at $37^{\circ} \mathrm{C}$. Cells were washed and lysed with NP-40 plus phosphatase inhibitors. Total lysates were subjected to overnight incubation at $4{ }^{\circ} \mathrm{C}$ with protein A-Sepharose beads (GE Healthcare) previously treated for $2 \mathrm{~h}$ with $2 \mu \mathrm{g}$ of polyclonal anti-WASp (H-250; Santa Cruz Biotechnology, Inc.). Bead-antibody-protein complexes were washed four times with lysis buffer and eluted with SDS-PAGE sample buffer. Immunoprecipitated proteins were separated by SDS-PAGE using 7.5\% polyacrylamide gel. Anti-phosphotyrosine and anti-WASp immunoblotting was performed using an anti-P-tyrosine (P-Tyr-100; Cell Signaling) and an anti-WASp monoclonal antibody (B-9; Santa Cruz Biotechnology, Inc.), respectively.

Immunofluorescence analysis. For the analysis of intracellular trafficking of $\mathrm{CpG}-\mathrm{A}$, splenic pDCs were isolated form the spleen of young animals (3 wk). Cells were pulsed with 10-20 $\mu \mathrm{g} / \mathrm{ml}$ FITC-labeled CpG-A for $30 \mathrm{~min}$ to $2 \mathrm{~h}$ as indicated in the text. In experiments with drug inhibitors, cells were incubated with cytochalasin-D for $30 \mathrm{~min}$ before incubation with CpG-A. For siRNA experiment control and WASp-specific siRNA, treated BM-pDCs or WT BM-pDCs were incubated with $3 \mu \mathrm{M}$ CpG-cy5 (SigmaAldrich). For IRF-7, nuclear translocation cells were incubated with unlabeled CpG-A for $2 \mathrm{~h}$. Fixed cells were labeled with goat anti-EEA-1 (Santa Cruz Biotechnology, Inc), LAMP-1 (553792; BD; directly coupled to Alexa Fluor 555 to avoid cross reactivity with antibodies used for isolation), or anti IRF-7 (Invitrogen). Confocal images were acquired in a reverse microscope (LSM 510 META Axiovert 200M; Carl Zeiss) with a $63 \times$ objective. EE volumes and CpG-A volumes were quantified on projections of $0.2 \mathrm{z}$ slices using Volocity software (Perkin Elmer, Inc). Colocalization between CpG-A and endosomes markers was measured manually on 3D reconstructed images, using Volocity software. To quantify nuclear translocation of IRF-7, we manually depicted two regions, one including the nucleus (based on DAPI signal) and the second covering the cytosol. The ratio between the intensities in the two regions was calculated and expressed as index of nuclear translocation.

Statistical analysis. Results were analyzed with Prism 5.0 (GraphPad Software). The tests used for statistical analysis are mentioned in the figure legends. A p-value $<0.05$ was taken as statistically significant. All graphs, unless otherwise specified, show mean \pm SEM.

The authors are grateful to Raffaella Vescovi (Department of Pathology, University of Brescia) for the excellent contribution to quantitative histological analysis. We thank Elisabetta Traggiai (Laboratory of Immunology and Rheumatic Disease, IGG Genoa) for providing control serum from SLE and JIA patients.

This work is funded by Italian Telethon GGP 10231. F. Prete is supported by an International Centre for Genetic Engineering and Biology predoctoral fellowship. W. Vermi is supported by PRIN (Ministero dell'Istruzione dell'Università e della Ricerca, 2009). M. Carmina Castiello conducted this study as partial fulfillment of her PhD in Molecular Medicine, Program in Basic and Applied Immunology, San Raffaele University, Milan, Italy. L.D. Notarangelo was partially supported by NIH-NHLBI grant 5P01HL059561-14.

The authors have no conflicting financial interests.

\section{Submitted: 15 February 2012}

Accepted: 17 December 2012

\section{REFERENCES}

Agrawal, H., N. Jacob, E. Carreras, S. Bajana, C. Putterman, S. Turner, B. Neas, A. Mathian, M.N. Koss, W. Stohl, et al. 2009. Deficiency of type I IFN receptor in lupus-prone New Zealand mixed 2328 mice decreases dendritic cell numbers and activation and protects from disease. J. Immunol. 183:6021-6029. http://dx.doi.org/10.4049/jimmunol.0803872

Altfeld, M., L. Fadda, D. Frleta, and N. Bhardwaj. 2011. DCs and NK cells: critical effectors in the immune response to HIV-1. Nat. Rev. Immunol. 11:176-186. http://dx.doi.org/10.1038/nri2935

Andreansky, S., H. Liu, S. Turner, J.A. McCullers, R. Lang, R. Rutschman, P.C. Doherty, P.J. Murray, A.W. Nienhuis, and T.S. Strom. 2005. 
WASP- mice exhibit defective immune responses to influenza A virus, Streptococcus pneumoniae, and Mycobacterium bovis BCG. Exp. Hematol. 33:443-451. http://dx.doi.org/10.1016/j.exphem.2004.12.006

Astrakhan, A., H.D. Ochs, and D.J. Rawlings. 2009. Wiskott-Aldrich syndrome protein is required for homeostasis and function of invariant NKT cells. J. Immunol. 182:7370-7380. http://dx.doi.org/10.4049/ jimmunol.0804256

Badour, K., J. Zhang, F. Shi, M.K. McGavin, V. Rampersad, L.A. Hardy, D. Field, and K.A. Siminovitch. 2003. The Wiskott-Aldrich syndrome protein acts downstream of CD2 and the CD2AP and PSTPIP1 adaptors to promote formation of the immunological synapse. Immunity. 18: 141-154. http://dx.doi.org/10.1016/S1074-7613(02)00516-2

Baechler, E.C., F.M. Batliwalla, G. Karypis, P.M. Gaffney, W.A. Ortmann, K.J. Espe, K.B. Shark, W.J. Grande, K.M. Hughes, V. Kapur, et al. 2003. Interferon-inducible gene expression signature in peripheral blood cells of patients with severe lupus. Proc. Natl. Acad. Sci. USA. 100:2610-2615. http://dx.doi.org/10.1073/pnas.0337679100

Baechler, E.C., J.W. Bauer, C.A. Slattery, W.A. Ortmann, K.J. Espe, J. Novitzke, S.R. Ytterberg, P.K. Gregersen, T.W. Behrens, and A.M. Reed. 2007. An interferon signature in the peripheral blood of dermatomyositis patients is associated with disease activity. Mol. Med. 13:5968. http://dx.doi.org/10.2119/2006-00085.Baechler

Barrat, F.J., T. Meeker, J. Gregorio, J.H. Chan, S. Uematsu, S. Akira, B. Chang, O. Duramad, and R.L. Coffman. 2005. Nucleic acids of mammalian origin can act as endogenous ligands for Toll-like receptors and may promote systemic lupus erythematosus. J. Exp. Med. 202:1131-1139. http://dx.doi.org/10.1084/jem.20050914

Båve, U., G.V. Alm, and L. Rönnblom. 2000. The combination of apoptotic U937 cells and lupus IgG is a potent IFN-alpha inducer. J. Immunol. 165:3519-3526.

Båve, U., G. Nordmark, T. Lövgren, J. Rönnelid, S. Cajander, M.L. Eloranta, G.V. Alm, and L. Rönnblom. 2005. Activation of the type I interferon system in primary Sjögren's syndrome: a possible etiopathogenic mechanism. Arthritis Rheum. 52:1185-1195. http://dx.doi.org/10.1002/art.20998

Becker-Herman, S., A. Meyer-Bahlburg, M.A. Schwartz, S.W. Jackson, K.L. Hudkins, C. Liu, B.D. Sather, S. Khim, D. Liggitt, W. Song, et al. 2011. WASp-deficient B cells play a critical, cell-intrinsic role in triggering autoimmunity. J. Exp. Med. 208:2033-2042. http://dx.doi .org/10.1084/jem.20110200

Björck, P. 2004. Dendritic cells exposed to herpes simplex virus in vivo do not produce IFN-alpha after rechallenge with virus in vitro and exhibit decreased T cell alloreactivity. J. Immunol. 172:5396-5404.

Blanco, P., A.K. Palucka, M. Gill, V. Pascual, and J. Banchereau. 2001. Induction of dendritic cell differentiation by IFN-alpha in systemic lupus erythematosus. Science. 294:1540-1543. http://dx.doi.org/10.1126/science.1064890

Blomberg, S., M.L. Eloranta, M. Magnusson, G.V. Alm, and L. Rönnblom. 2003. Expression of the markers BDCA-2 and BDCA-4 and production of interferon-alpha by plasmacytoid dendritic cells in systemic lupus erythematosus. Arthritis Rheum. 48:2524-2532. http://dx.doi .org/10.1002/art.11225

Bosticardo, M., F. Marangoni, A. Aiuti, A. Villa, and M. Grazia Roncarolo. 2009. Recent advances in understanding the pathophysiology of Wiskott-Aldrich syndrome. Blood.113:6288-6295. http://dx.doi.org/10 .1182/blood-2008-12-115253

Bosticardo, M., E. Draghici, F. Schena, A.V. Sauer, E. Fontana, M.C. Castiello, M. Catucci, M. Locci, L. Naldini, A. Aiuti, et al. 2011. Lentiviralmediated gene therapy leads to improvement of B-cell functionality in a murine model of Wiskott-Aldrich syndrome. J. Allergy Clin. Immunol. 127:1376-1384: e5. http://dx.doi.org/10.1016/j.jaci.2011.03.030

Bouma, G., A. Mendoza-Naranjo, M.P. Blundell, E. de Falco, K.L. Parsley, S.O. Burns, and A.J. Thrasher. 2011. Cytoskeletal remodeling mediated by WASp in dendritic cells is necessary for normal immune synapse formation and T-cell priming. Blood. 118:2492-2501. http://dx.doi.org/ 10.1182/blood-2011-03-340265

Cancro, M.P., D.P. D'Cruz, and M.A. Khamashta. 2009. The role of B lymphocyte stimulator (BLyS) in systemic lupus erythematosus. J. Clin. Invest. 119:1066-1073. http://dx.doi.org/10.1172/JCI38010

Cao, H., J.D. Orth, J. Chen, S.G. Weller, J.E. Heuser, and M.A. McNiven. 2003. Cortactin is a component of clathrin-coated pits and participates in receptor-mediated endocytosis. Mol. Cell. Biol. 23:2162-2170. http:// dx.doi.org/10.1128/MCB.23.6.2162-2170.2003

de Noronha, S., S. Hardy, J. Sinclair, M.P. Blundell, J. Strid, O. Schulz, J. Zwirner, G.E. Jones, D.R. Katz, C. Kinnon, and A.J. Thrasher. 2005. Impaired dendritic-cell homing in vivo in the absence of WiskottAldrich syndrome protein. Blood. 105:1590-1597. http://dx.doi.org/ 10.1182/blood-2004-06-2332

Derivery, E., C. Sousa, J.J. Gautier, B. Lombard, D. Loew, and A. Gautreau. 2009. The Arp2/3 activator WASH controls the fission of endosomes through a large multiprotein complex. Dev. Cell. 17:712-723. http:// dx.doi.org/10.1016/j.devcel.2009.09.010

Ding, D., H. Mehta, W.J. McCune, and M.J. Kaplan. 2006. Aberrant phenotype and function of myeloid dendritic cells in systemic lupus erythematosus. J. Immunol. 177:5878-5889.

Duan, X.Z., M. Wang, H.W. Li, H. Zhuang, D. Xu, and F.S. Wang. 2004 Decreased frequency and function of circulating plasmocytoid dendritic cells (pDC) in hepatitis B virus infected humans. J. Clin. Immunol. 24:637-646. http://dx.doi.org/10.1007/s10875-004-6249-y

Dupré, L., A. Aiuti, S. Trifari, S. Martino, P. Saracco, C. Bordignon, and M.G. Roncarolo. 2002. Wiskott-Aldrich syndrome protein regulates lipid raft dynamics during immunological synapse formation. Immunity. 17:157-166. http://dx.doi.org/10.1016/S1074-7613(02)00360-6

Dupuis-Girod, S., J. Medioni, E. Haddad, P. Quartier, M. Cavazzana-Calvo, F. Le Deist, G. de Saint Basile, J. Delaunay, K. Schwarz, J.L. Casanova, et al. 2003. Autoimmunity in Wiskott-Aldrich syndrome: risk factors, clinical features, and outcome in a single-center cohort of 55 patients. Pediatrics. 111:e622-e627. http://dx.doi.org/10.1542/peds.111.5.e622

Emamian, E.S., J.M. Leon, C.J. Lessard, M. Grandits, E.C. Baechler, P.M. Gaffney, B. Segal, N.L. Rhodus, and K.L. Moser. 2009. Peripheral blood gene expression profiling in Sjögren's syndrome. Genes Immun. 10:285-296. http://dx.doi.org/10.1038/gene.2009.20

Escoll, P., C. del Fresno, L. García, G. Vallés, M.J. Lendínez, F. Arnalich, and E. López-Collazo. 2003. Rapid up-regulation of IRAK-M expression following a second endotoxin challenge in human monocytes and in monocytes isolated from septic patients. Biochem. Biophys. Res. Commun. 311:465-472. http://dx.doi.org/10.1016/j.bbrc.2003.10.019

Fleck, M., E.R. Kern, T. Zhou, B. Lang, and J.D. Mountz. 1998. Murine cytomegalovirus induces a Sjögren's syndrome-like disease in C57Bl/6-lpr/lpr mice. Arthritis Rheum. 41:2175-2184. http://dx.doi.org/10.1002/15290131(199812)41:12<2175::AID-ART12>3.0.CO;2-I

Gallego, M.D., M.A. de la Fuente, I.M. Anton, S. Snapper, R. Fuhlbrigge, and R.S. Geha. 2006. WIP and WASP play complementary roles in T cell homing and chemotaxis to SDF-1alpha. Int. Immunol. 18:221-232. http://dx.doi.org/10.1093/intimm/dxh310

Garcia-Romo, G.S., S. Caielli, B. Vega, J. Connolly, F. Allantaz, Z. Xu, M. Punaro, J. Baisch, C. Guiducci, R.L. Coffman, et al. 2011. Netting neutrophils are major inducers of type I IFN production in pediatric systemic lupus erythematosus. Sci. Transl. Med. 3:73ra20. http://dx.doi .org/10.1126/scitranslmed.3001201

Gilliet, M., and R. Lande. 2008. Antimicrobial peptides and self-DNA in autoimmune skin inflammation. Curr. Opin. Immunol. 20:401-407. http://dx.doi.org/10.1016/j.coi.2008.06.008

Gilliet, M., W. Cao, and Y.J. Liu. 2008. Plasmacytoid dendritic cells: sensing nucleic acids in viral infection and autoimmune diseases. Nat. Rev. Immunol. 8:594-606. http://dx.doi.org/10.1038/nri2358

Gismondi, A., L. Cifaldi, C. Mazza, S. Giliani, S. Parolini, S. Morrone, J. Jacobelli, E. Bandiera, L. Notarangelo, and A. Santoni. 2004. Impaired natural and CD16-mediated NK cell cytotoxicity in patients with WAS and XLT: ability of IL-2 to correct NK cell functional defect. Blood. 104:436-443. http://dx.doi.org/10.1182/blood-2003-07-2621

Gottenberg, J.E., N. Cagnard, C. Lucchesi, F. Letourneur, S. Mistou, T. Lazure, S. Jacques, N. Ba, M. Ittah, C. Lepajolec, et al. 2006. Activation of IFN pathways and plasmacytoid dendritic cell recruitment in target organs of primary Sjögren's syndrome. Proc. Natl. Acad. Sci. USA. 103:2770-2775. http://dx.doi.org/10.1073/pnas.0510837103

Guiducci, C., G. Ott, J.H. Chan, E. Damon, C. Calacsan, T. Matray, K.D. Lee, R.L. Coffman, and F.J. Barrat. 2006. Properties regulating the nature of the plasmacytoid dendritic cell response to Toll-like receptor 9 activation. J. Exp. Med. 203:1999-2008. http://dx.doi.org/10.1084/jem.20060401 
Honda, K., Y. Ohba, H. Yanai, H. Negishi, T. Mizutani, A. Takaoka, C. Taya, and T. Taniguchi. 2005. Spatiotemporal regulation of MyD88IRF-7 signalling for robust type-I interferon induction. Nature. 434:1035-1040. http://dx.doi.org/10.1038/nature03547

Humblet-Baron, S., B. Sather, S. Anover, S. Becker-Herman, D.J. Kasprowicz, S. Khim, T. Nguyen, K. Hudkins-Loya, C.E. Alpers, S.F. Ziegler, et al. 2007. Wiskott-Aldrich syndrome protein is required for regulatory T cell homeostasis. J. Clin. Invest. 117:407-418. http:// dx.doi.org/10.1172/JCI29539

Humphreys-Beher, M.G. 1996. Animal models for autoimmune diseaseassociated xerostomia and xerophthalmia. Adv. Dent. Res. 10:73-75. http://dx.doi.org/10.1177/08959374960100011501

Imai, K., T. Morio, Y. Zhu, Y. Jin, S. Itoh, M. Kajiwara, J. Yata, S. Mizutani, H.D. Ochs, and S. Nonoyama. 2004. Clinical course of patients with WASP gene mutations. Blood. 103:456-464. http://dx.doi .org/10.1182/blood-2003-05-1480

Ito, T., H. Kanzler, O. Duramad, W. Cao, and Y.J. Liu. 2006. Specialization, kinetics, and repertoire of type 1 interferon responses by human plasmacytoid predendritic cells. Blood. 107:2423-2431. http://dx.doi.org/ 10.1182/blood-2005-07-2709

Itoh, T., K.S. Erdmann, A. Roux, B. Habermann, H. Werner, and P. De Camilli. 2005. Dynamin and the actin cytoskeleton cooperatively regulate plasma membrane invagination by BAR and F-BAR proteins. Dev. Cell. 9:791-804. http://dx.doi.org/10.1016/j.devcel.2005.11.005

Jego, G., A.K. Palucka, J.P. Blanck, C. Chalouni, V. Pascual, and J. Banchereau. 2003. Plasmacytoid dendritic cells induce plasma cell differentiation through type I interferon and interleukin 6. Immunity. 19:225-234. http://dx.doi.org/10.1016/S1074-7613(03)00208-5

Jin, Y., C. Mazza, J.R. Christie, S. Giliani, M. Fiorini, P. Mella, F. Gandellini, D.M. Stewart, Q. Zhu, D.L. Nelson, et al. 2004. Mutations of the Wiskott-Aldrich Syndrome Protein (WASP): hotspots, effect on transcription, and translation and phenotype/genotype correlation. Blood. 104:4010-4019. http://dx.doi.org/10.1182/blood-2003-05-1592

Kaksonen, M., C.P. Toret, and D.G. Drubin. 2005. A modular design for the clathrin- and actin-mediated endocytosis machinery. Cell. 123:305320. http://dx.doi.org/10.1016/j.cell.2005.09.024

Kanto, T., M. Inoue, H. Miyatake, A. Sato, M. Sakakibara, T. Yakushijin, C. Oki, I. Itose, N. Hiramatsu, T. Takehara, et al. 2004. Reduced numbers and impaired ability of myeloid and plasmacytoid dendritic cells to polarize $\mathrm{T}$ helper cells in chronic hepatitis $\mathrm{C}$ virus infection. J. Infect. Dis. 190:1919-1926. http://dx.doi.org/10.1086/425425

Kwok, S.K., J.Y. Lee, S.H. Park, M.L. Cho, S.Y. Min, S.H. Park, H.Y. Kim, and Y.G. Cho. 2008a. Dysfunctional interferon-alpha production by peripheral plasmacytoid dendritic cells upon Toll-like receptor-9 stimulation in patients with systemic lupus erythematosus. Arthritis Res. Ther. 10:R29. http://dx.doi.org/10.1186/ar2382

Kwok, S.K., S.H. Seo, J.H. Ju, C.H. Yoon, S.C. Park, B.S. Kim, H.Y. Kim, and S.H. Park. 2008b. Cryptococcal meningitis presenting with isolated sixth cranial nerve palsy in a patient with systemic lupus erythematosus. J. Korean Med. Sci. 23:153-155. http://dx.doi.org/10.3346/ jkms.2008.23.1.153

Lande, R., J. Gregorio, V. Facchinetti, B. Chatterjee, Y.H. Wang, B. Homey, W. Cao, Y.H. Wang, B. Su, F.O. Nestle, et al. 2007. Plasmacytoid dendritic cells sense self-DNA coupled with antimicrobial peptide. Nature. 449:564-569. http://dx.doi.org/10.1038/nature06116

Latz, E., A. Schoenemeyer, A. Visintin, K.A. Fitzgerald, B.G. Monks, C.F. Knetter, E. Lien, N.J. Nilsen, T. Espevik, and D.T. Golenbock. 2004. TLR9 signals after translocating from the ER to CpG DNA in the lysosome. Nat. Immunol. 5:190-198. http://dx.doi.org/10.1038/ni1028

Le Bon, A., V. Durand, E. Kamphuis, C. Thompson, S. Bulfone-Paus, C. Rossmann, U. Kalinke, and D.F. Tough. 2006a. Direct stimulation of $\mathrm{T}$ cells by type I IFN enhances the CD8+ T cell response during crosspriming. J. Immunol. 176:4682-4689.

Le Bon, A., C. Thompson, E. Kamphuis, V. Durand, C. Rossmann, U. Kalinke, and D.F. Tough. 2006b. Cutting edge: enhancement of antibody responses through direct stimulation of $\mathrm{B}$ and $\mathrm{T}$ cells by type $\mathrm{I}$ IFN. J. Immunol. 176:2074-2078.

Leverrier, Y., R. Lorenzi, M.P. Blundell, P. Brickell, C. Kinnon, A.J. Ridley, and A.J. Thrasher. 2001. Cutting edge: the Wiskott-Aldrich syndrome protein is required for efficient phagocytosis of apoptotic cells. J. Immunol. 166:4831-4834.

Litinskiy, M.B., B. Nardelli, D.M. Hilbert, B. He, A. Schaffer, P. Casali, and A. Cerutti. 2002. DCs induce CD40-independent immunoglobulin class switching through BLyS and APRIL. Nat. Immunol. 3:822-829. http://dx.doi.org/10.1038/ni829

Locci, M., E. Draghici, F. Marangoni, M. Bosticardo, M. Catucci, A. Aiuti, C. Cancrini, L. Marodi, T. Espanol, R.G. Bredius, et al. 2009. The Wiskott-Aldrich syndrome protein is required for iNKT cell maturation and function. J. Exp. Med. 206:735-742. http://dx.doi.org/ 10.1084/jem.20081773

Lorenzi, R., P.M. Brickell, D.R. Katz, C. Kinnon, and A.J. Thrasher. 2000. Wiskott-Aldrich syndrome protein is necessary for efficient IgG-mediated phagocytosis. Blood. 95:2943-2946.

Lövgren, T., M.L. Eloranta, U. Båve, G.V. Alm, and L. Rönnblom. 2004 Induction of interferon-alpha production in plasmacytoid dendritic cells by immune complexes containing nucleic acid released by necrotic or late apoptotic cells and lupus IgG. Arthritis Rheum. 50:1861-1872. http://dx.doi.org/10.1002/art.20254

Maillard, M.H., V. Cotta-de-Almeida, F. Takeshima, D.D. Nguyen, P. Michetti, C. Nagler, A.K. Bhan, and S.B. Snapper. 2007. The Wiskott-Aldrich syndrome protein is required for the function of CD $4{ }^{+} \mathrm{CD} 25^{+} \mathrm{Foxp}^{+}{ }^{+}$regulatory T cells. J. Exp. Med. 204:381-391. http://dx.doi.org/10.1084/jem.20061338

Marangoni, F., S. Trifari, S. Scaramuzza, C. Panaroni, S. Martino, L.D. Notarangelo, Z. Baz, A. Metin, F. Cattaneo, A. Villa, et al. 2007. WASP regulates suppressor activity of human and murine $\mathrm{CD} 4^{+} \mathrm{CD} 25^{+} \mathrm{FOXP3}{ }^{+}$ natural regulatory T cells. J. Exp. Med. 204:369-380. http://dx.doi.org/ $10.1084 / \mathrm{jem} .20061334$

Means, T.K., E. Latz, F. Hayashi, M.R. Murali, D.T. Golenbock, and A.D. Luster. 2005. Human lupus autoantibody-DNA complexes activate DCs through cooperation of CD32 and TLR9. J. Clin. Invest. 115:407-417.

Merrifield, C.J., D. Perrais, and D. Zenisek. 2005. Coupling between clathrin-coated-pit invagination, cortactin recruitment, and membrane scission observed in live cells. Cell. 121:593-606. http://dx.doi.org/ 10.1016/j.cell.2005.03.015

Meyer-Bahlburg, A., S. Becker-Herman, S. Humblet-Baron, S. Khim, M. Weber, G. Bouma, A.J. Thrasher, F.D. Batista, and D.J. Rawlings. 2008. Wiskott-Aldrich syndrome protein deficiency in B cells results in impaired peripheral homeostasis. Blood. 112:4158-4169. http://dx.doi .org/10.1182/blood-2008-02-140814

Migita, K., T. Miyashita, Y. Maeda, H. Kimura, M. Nakamura, H. Yatsuhashi, H. Ishibashi, and K. Eguchi. 2005. Reduced blood BDCA$2+$ (lymphoid) and CD11c+ (myeloid) dendritic cells in systemic lupus erythematosus. Clin. Exp. Immunol. 142:84-91. http://dx.doi.org/ 10.1111/j.1365-2249.2005.02897.x

Morales-Tirado, V., S. Johannson, E. Hanson, A. Howell, J. Zhang, K.A. Siminovitch, and D.J. Fowell. 2004. Cutting edge: selective requirement for the Wiskott-Aldrich syndrome protein in cytokine, but not chemokine, secretion by CD4+ T cells. J. Immunol. 173:726-730.

Murai, M., O. Turovskaya, G. Kim, R. Madan, C.L. Karp, H. Cheroutre, and M. Kronenberg. 2009. Interleukin 10 acts on regulatory T cells to maintain expression of the transcription factor Foxp3 and suppressive function in mice with colitis. Nat. Immunol. 10:1178-1184. http:// dx.doi.org/10.1038/ni.1791

Nestle, F.O., C. Conrad, A. Tun-Kyi, B. Homey, M. Gombert, O. Boyman, G. Burg, Y.J. Liu, and M. Gilliet. 2005. Plasmacytoid predendritic cells initiate psoriasis through interferon- $\alpha$ production. J. Exp. Med. 202:135-143. http://dx.doi.org/10.1084/jem.20050500

Nguyen, D.D., M.A. Wurbel, J.A. Goettel, M.A. Eston, O.S. Ahmed, R. Marin, E.K. Boden, E.J. Villablanca, H. Paidassi, V. Ahuja, et al. 2012. Wiskott-Aldrich syndrome protein deficiency in innate immune cells leads to mucosal immune dysregulation and colitis in mice. Gastroenterology. 143:719-729: e1-e2. http://dx.doi.org/10.1053/j.gastro.2012.06.008

Nikolov, N.P., M. Shimizu, S. Cleland, D. Bailey, J. Aoki, T. Strom, P.L. Schwartzberg, F. Candotti, and R.M. Siegel. 2010. Systemic autoimmunity and defective Fas ligand secretion in the absence of the Wiskott-Aldrich syndrome protein. Blood. 116:740-747. http://dx.doi .org/10.1182/blood-2009-08-237560 
Ohashi, E., K. Tanabe,Y. Henmi, K. Mesaki,Y. Kobayashi, and K. Takei. 2011 Receptor sorting within endosomal trafficking pathway is facilitated by dynamic actin filaments. PLoS ONE. 6:e19942. http://dx.doi.org/ 10.1371/journal.pone.0019942

Orange, J.S., N. Ramesh, E. Remold-O'Donnell, Y. Sasahara, L. Koopman, M. Byrne, F.A. Bonilla, F.S. Rosen, R.S. Geha, and J.L. Strominger. 2002. Wiskott-Aldrich syndrome protein is required for NK cell cytotoxicity and colocalizes with actin to NK cell-activating immunologic synapses. Proc. Natl. Acad. Sci. USA. 99:11351-11356. http://dx.do .org/10.1073/pnas.162376099

Pascual, V., D. Chaussabel, and J. Banchereau. 2010. A genomic approach to human autoimmune diseases. Annu. Rev. Immunol. 28:535-571. http:// dx.doi.org/10.1146/annurev-immunol-030409-101221

Pau, E., Y.H. Cheung, C. Loh, G. Lajoie, and J.E. Wither. 2012. TLR tolerance reduces IFN-alpha production despite plasmacytoid dendritic cell expansion and anti-nuclear antibodies in NZB bicongenic mice. PLoS ONE. 7:e36761. http://dx.doi.org/10.1371/journal.pone.0036761

Presicce, P., A. Taddeo, A. Conti, M.L. Villa, and S. Della Bella. 2008. Keyhole limpet hemocyanin induces the activation and maturation of human dendritic cells through the involvement of mannose receptor. Mol. Immunol. 45:1136-1145. http://dx.doi.org/10.1016/ j.molimm.2007.07.020

Prinz, M., H. Schmidt, A. Mildner, K.P. Knobeloch, U.K. Hanisch, J. Raasch, D. Merkler, C. Detje, I. Gutcher, J. Mages, et al. 2008. Distinct and nonredundant in vivo functions of IFNAR on myeloid cells limit autoimmunity in the central nervous system. Immunity. 28:675-686. http://dx.doi.org/10.1016/j.immuni.2008.03.011

Pulecio, J., E. Tagliani, A. Scholer, F. Prete, L. Fetler, O.R. Burrone, and F. Benvenuti. 2008. Expression of Wiskott-Aldrich syndrome protein in dendritic cells regulates synapse formation and activation of naive CD8+ T cells. J. Immunol. 181:1135-1142.

Recher, M., S.O. Burns, M.A. de la Fuente, S. Volpi, C. Dahlberg, J.E. Walter, K. Moffitt, D. Mathew, N. Honke, P.A. Lang, et al. 2012. B cell-intrinsic deficiency of the Wiskott-Aldrich syndrome protein (WASp) causes severe abnormalities of the peripheral B-cell compartment in mice. Blood. 119:2819-2828. http://dx.doi.org/10.1182/blood-2011-09-379412

Sanjuan, M.A., N. Rao, K.T. Lai, Y. Gu, S. Sun, A. Fuchs, W.P. Fung-Leung, M. Colonna, and L. Karlsson. 2006. CpG-induced tyrosine phosphorylation occurs via a TLR9-independent mechanism and is required for cytokine secretion. J. Cell Biol. 172:1057-1068. http://dx.doi.org/ $10.1083 / \mathrm{jcb} .200508058$

Santiago-Raber, M.L., R. Baccala, K.M. Haraldsson, D. Choubey, T.A. Stewart, D.H. Kono, and A.N. Theofilopoulos. 2003. Type-I interferon receptor deficiency reduces lupus-like disease in NZB mice. J. Exp. Med. 197:777-788. http://dx.doi.org/10.1084/jem.20021996

Sasahara, Y., R. Rachid, M.J. Byrne, M.A. de la Fuente, R.T. Abraham, N. Ramesh, and R.S. Geha. 2002. Mechanism of recruitment of WASP to the immunological synapse and of its activation following TCR ligation. Mol. Cell. 10:1269-1281. http://dx.doi.org/10.1016/S1097-2765(02)00728-1

Sasai, M., and A. Iwasaki. 2011. Love triangle between Unc93B1, TLR7, and TLR 9 prevents fatal attraction. Immunity. 35:3-5. http://dx.doi.org/ 10.1016/j.immuni.2011.07.006

Sasai, M., M.M. Linehan, and A. Iwasaki. 2010. Bifurcation of Toll-like receptor 9 signaling by adaptor protein 3. Science. 329:1530-1534. http://dx.doi.org/10.1126/science.1187029

Shimizu, M., N.P. Nikolov, K. Ueno, K. Ohta, R.M. Siegel, A. Yachie, and F Candotti.2012.Development of IgA nephropathy-like glomerulonephritis associated with Wiskott-Aldrich syndrome protein deficiency. Clin. Immunol. 142:160-166. http://dx.doi.org/10.1016/j.clim.2011.10.001

Sims, T.N., T.J. Soos, H.S. Xenias, B. Dubin-Thaler, J.M. Hofman, J.C. Waite, T.O. Cameron, V.K. Thomas, R. Varma, C.H. Wiggins, et al. 2007. Opposing effects of PKCtheta and WASp on symmetry breaking and relocation of the immunological synapse. Cell. 129:773-785. http://dx.doi.org/10.1016/j.cell.2007.03.037

Snapper, S.B., F.S. Rosen, E. Mizoguchi, P. Cohen, W. Khan, C.H. Liu, T.L. Hagemann, S.P. Kwan, R. Ferrini, L. Davidson, et al. 1998. WiskottAldrich syndrome protein-deficient mice reveal a role for WASP in $\mathrm{T}$ but not $\mathrm{B}$ cell activation. Immunity. 9:81-91. http://dx.doi.org/ 10.1016/S1074-7613(00)80590-7
Snapper, S.B., P. Meelu, D. Nguyen, B.M. Stockton, P. Bozza, F.W. Alt, F.S Rosen, U.H. von Andrian, and C. Klein. 2005. WASP deficiency leads to global defects of directed leukocyte migration in vitro and in vivo. J. Leukoc. Biol. 77:993-998. http://dx.doi.org/10.1189/jlb.0804444

Strom, T.S., S.J. Turner, S. Andreansky, H. Liu, P.C. Doherty, D.K. Srivastava, J.M. Cunningham, and A.W. Nienhuis. 2003. Defects in Tcell-mediated immunity to influenza virus in murine Wiskott-Aldrich syndrome are corrected by oncoretroviral vector-mediated gene transfer into repopulating hematopoietic cells. Blood. 102:3108-3116. http:// dx.doi.org/10.1182/blood-2002-11-3489

Takenawa, T., and S. Suetsugu. 2007. The WASP-WAVE protein network: connecting the membrane to the cytoskeleton. Nat. Rev. Mol. Cell Biol. 8:37-48. http://dx.doi.org/10.1038/nrm2069

Thrasher, A.J., and S.O. Burns. 2010. WASP: a key immunological multitasker. Nat. Rev. Immunol. 10:182-192. http://dx.doi.org/10.1038/ nri2724

Trifari, S., G. Sitia, A. Aiuti, S. Scaramuzza, F. Marangoni, L.G. Guidotti, S. Martino, P. Saracco, L.D. Notarangelo, M.G. Roncarolo, and L. Dupré. 2006. Defective Th1 cytokine gene transcription in CD4+ and CD8+ T cells from Wiskott-Aldrich syndrome patients. J. Immunol. 177:7451-7461.

Trifari, S., S. Scaramuzza, M. Catucci, M. Ponzoni, L. Mollica, R. Chiesa, F. Cattaneo, F. Lafouresse, R. Calvez, W. Vermi, et al. 2010. Revertant T lymphocytes in a patient with Wiskott-Aldrich syndrome: analysis of function and distribution in lymphoid organs. J. Allergy Clin. Immunol. 125:439-448: e8. http://dx.doi.org/10.1016/j.jaci.2009.11.034

Tsuboi, S. 2007. Requirement for a complex of Wiskott-Aldrich syndrome protein (WASP) with WASP interacting protein in podosome formation in macrophages. J. Immunol. 178:2987-2995.

Vallin, H., A. Perers, G.V. Alm, and L. Rönnblom. 1999. Anti-doublestranded DNA antibodies and immunostimulatory plasmid DNA in combination mimic the endogenous IFN-alpha inducer in systemic lupus erythematosus. J. Immunol. 163:6306-6313.

van Baarsen, L.G., C.L. Bos, T.C. van der Pouw Kraan, and C.L. Verweij. 2009. Transcription profiling of rheumatic diseases. Arthritis Res. Ther. 11:207. http://dx.doi.org/10.1186/ar2557

van der Pouw Kraan, T.C., C.A. Wijbrandts, L.G. van Baarsen, A.E. Voskuyl, F. Rustenburg, J.M. Baggen, S.M. Ibrahim, M. Fero, B.A. Dijkmans, P.P. Tak, and C.L. Verweij. 2007. Rheumatoid arthritis subtypes identified by genomic profiling of peripheral blood cells: assignment of a type I interferon signature in a subpopulation of patients. Ann. Rheum. Dis. 66:1008-1014. http://dx.doi.org/10.1136/ard.2006.063412

Vermi, W., L. Blanzuoli, M.D. Kraus, P. Grigolato, F. Donato, G. Loffredo, C.E. Marino, D. Alberti, L.D. Notarangelo, and F. Facchetti. 1999. The spleen in the Wiskott-Aldrich syndrome: histopathologic abnormalities of the white pulp correlate with the clinical phenotype of the disease. Am. J. Surg. Pathol. 23:182-191. http://dx.doi.org/10 .1097/00000478-199902000-00007

Vermi, W., M. Soncini, L. Melocchi, S. Sozzani, and F. Facchetti. 2011. Plasmacytoid dendritic cells and cancer. J. Leukoc. Biol. 90:681-690. http://dx.doi.org/10.1189/jlb.0411190

Wengler, G.S., L.D. Notarangelo, S. Giliani, M.G. Pirastru, A.G. Ugazio, and O. Parolini. 1995. Mutation analysis in Wiskott Aldrich syndrome on chorionic villus DNA. Lancet. 346:641-642. http://dx.doi .org/10.1016/S0140-6736(95)91477-3

Westerberg, L., M. Larsson, S.J. Hardy, C. Fernández, A.J. Thrasher, and E. Severinson. 2005. Wiskott-Aldrich syndrome protein deficiency leads to reduced $\mathrm{B}$-cell adhesion, migration, and homing, and a delayed humoral immune response. Blood. 105:1144-1152. http://dx.doi .org/10.1182/blood-2004-03-1003

Westerberg, L.S., M.A. de la Fuente, F. Wermeling, H.D. Ochs, M.C. Karlsson, S.B. Snapper, and L.D. Notarangelo. 2008. WASP confers selective advantage for specific hematopoietic cell populations and serves a unique role in marginal zone B-cell homeostasis and function. Blood. 112:4139-4147. http://dx.doi.org/10.1182/blood-2008-02-140715

Zhu, Q., C. Watanabe, T. Liu, D. Hollenbaugh, R.M. Blaese, S.B. Kanner, A. Aruffo, and H.D. Ochs. 1997. Wiskott-Aldrich syndrome/X-linked thrombocytopenia: WASP gene mutations, protein expression, and phenotype. Blood. 90:2680-2689. 